\title{
Exosomes Could Offer New Options to Combat the Long-Term Complications Inflicted by Gestational Diabetes Mellitus
}

\author{
Juliana Ferreira Floriano ${ }^{1}$, Gareth Willis ${ }^{2}$, Francesco Catapano ${ }^{3}$, Patrícia Rodrigues de Lima ${ }^{1}$, \\ Fabiana Vieira Duarte Souza Reis ${ }^{1}$, Angélica Mercia Pascon Barbosa ${ }^{1}$ (D, \\ Marilza Vieira Cunha Rudge ${ }^{1, *(D)}$ and Costanza Emanueli ${ }^{3, *}$ \\ 1 Botucatu Medical School, Sao Paulo State University, 18618687 Botucatu, Brazil; \\ juliana.floriano@unesp.br (J.F.F.); patriciarl.lima@gmail.com (P.R.d.L.); \\ fabianavdsreis@gmail.com (F.V.D.S.R.); angelicapascon@gmail.com (A.M.P.B.) \\ 2 Division of Newborn Medicine/Children's Hospital, Harvard Medical School, Boston, MA 02115, USA; \\ Gareth.Willis@childrens.harvard.edu \\ 3 National Heart and Lung Institute, Imperial College London, London W12 0NN, UK; \\ f.catapano@imperial.ac.uk \\ * Correspondence: marilzarudge@gmail.com (M.V.C.R.); c.emanueli@imperial.ac.uk (C.E.); \\ Tel.: +44-2075943409 (C.E.)
}

Received: 4 January 2020; Accepted: 29 February 2020; Published: 10 March 2020

check for updates

\begin{abstract}
Gestational diabetes Mellitus (GDM) is a complex clinical condition that promotes pelvic floor myopathy, thus predisposing sufferers to urinary incontinence (UI). GDM usually regresses after birth. Nonetheless, a GDM history is associated with higher risk of subsequently developing type 2 diabetes, cardiovascular diseases (CVD) and UI. Some aspects of the pathophysiology of GDM remain unclear and the associated pathologies (outcomes) are poorly addressed, simultaneously raising public health costs and diminishing women's quality of life. Exosomes are small extracellular vesicles produced and actively secreted by cells as part of their intercellular communication system. Exosomes are heterogenous in their cargo and depending on the cell sources and environment, they can mediate both pathogenetic and therapeutic functions. With the advancement in knowledge of exosomes, new perspectives have emerged to support the mechanistic understanding, prediction/diagnosis and ultimately, treatment of the post-GMD outcomes. Here, we will review recent advances in knowledge of the role of exosomes in GDM and related areas and discuss the possibilities for translating exosomes as therapeutic agents in the GDM clinical setting.
\end{abstract}

Keywords: gestational diabetes mellitus; outcomes; urinary incontinence; therapy; exosomes; microRNAs

\section{Gestational Diabetes Mellitus}

Gestational diabetes mellitus (GDM) is an increasingly common condition, affecting approximately $8.3 \%$ of pregnancies [1] worldwide. GDM occurs when insulin resistance exceeds the capacity for insulin secretion. The resulting insulin imbalance leads to vascular inflammation $[2,3]$ and predisposes women to the risk of developing more severe pathologies [4].

Currently, the mechanisms underpinning GDM development are poorly understood, as well as the concomitant complications caused by a GDM pregnancy in mother and offspring. The risk of type 2 diabetes mellitus (T2DM) and cardiovascular diseases (CVD) rates, are rising alarmingly in the general population and is further increased for both mother and child after a GDM pregnancy [5-7]. Furthermore, for the mother, GDM is a strong predictor of urinary incontinence (UI) up to two years 
postpartum even in cases of cesarean section, where there is no vaginal distention, due to gestational diabetic myopathy [8-10].

UI dramatically diminishes women's' quality of life and represents a considerable economic burden for both patients and public health [11-14]. Hyperglycemia and reduced insulin signaling are deleterious for skeletal muscle cell metabolism and might indeed play a relevant role in GDM-associated pelvic muscle degeneration and atrophy [15-22]. Additional skeletal muscle changes leading to muscle weakness can result directly and/or indirectly from altered CCL7, relaxin, insulin, glucose, parathyroid hormone $(\mathrm{PTH})$, calcium $(\mathrm{Ca})$, calcitonin and vitamin D levels, chemokines, proteins and growth factors that can enact tissue homeostasis [23-26] and induce structural changes in skeletal muscle, decreasing the number of mitochondria, the functional capacity and leading to muscle weakness [27,28]. Additional GDM-related changes include hormones-related connective tissue remodeling that are still poorly understood in GDM [29]. There is no effective treatment for gestational diabetic myopathy. However, the treatment for UI is ineffective in a large proportion of the population, thus increasing public health costs, social spending and diminishing the quality of life of the affected women. Increased clarity on the pathways underlying GDM is therefore needed for preventing and minimizing GDM-associated manifestations [17-22].

\section{Exosomes}

Exosomes are small ( $50-150 \mathrm{~nm}$ in diameter) extracellular vesicles (EVs), which are actively secreted by all cell types. They were accidentally discovered in 1983 by Rose M Johnstone and Bin-Tao Pan $[30,31]$ whilst they were studying how iron enters maturing red blood cells. These first studies suggested their function as being an alternative to lysosomal degradation [32,33] allowing the discard of transferrin receptors, which had become useless in mature red blood cells [31]. At the same year Harding et al., 1983, found the same results suggesting that transferrin is internalized via coated pits and vesicles, they demonstrated that transferrin and its receptor are recycled back to the plasma membrane after endocytosis [34]. Since this inglorious debut as refuse clearance operators, exosomes have climbed the ladder of significance quite dramatically. Today, exosomes are recognized as important actors in cell to cell communication [32,33,35-38]. Several reports have shown that exosomes play important roles in a diverse array of physiological actions, including the immune response, tumor progression and neurodegenerative disorders [33,35].

Exosomes contain multifarious cargos including proteins, mRNAs and miRNAs and other cytosol components enclosed in a lipid bilayer [36-38]. They can shield their cargo content from enzymatic degradation. This ability is fundamental for intercellular communication. In fact, exosomes can shuttle their biologically active cargos from the parent cell to induce expressional and functional response in their recipient cells $[39,40]$. The modalities of exosomes-based communications potentially allow for the combination of multiple actions: exosomes released from the same MVBs could support pools of ligands able to engage different cell-surface receptors simultaneously, mimicking interaction between two cells but without the need for direct cell-to-cell contact. Exosomes binding to recipient cell membrane could also provide the beneficiary cells with 'new' surface molecules, permitting an increase in the range of cell targeting and potentially acquiring new adhesion properties [33]. Exosomes participate in the maintenance of normal tissue and cell physiology for example, stem cell maintenance [41], tissue repair [42], immune surveillance [43] and blood coagulation [44]. Exosomes have also been linked to pathogenic mechanisms in cancer [45-47], virus infection [48], neurological degenerative diseases [49] and pregnancy complications by GDM or preeclampsia [50-54].

Exosomes are released from a variety of cell types into the extracellular space $[32,55,56]$ and are present in many biological fluids, including plasma, serum, amniotic fluid, urine and breast milk $[46,57,58]$. The concentration and content of circulating exosomes are potentially a rich source for novel clinical biomarkers and could additionally help in deciphering the mechanisms underpinning GDM complications, thus aiding in identification of new targets for therapeutic intervention [9,59-61]. On the other hand, as extensively described in this article, the discovery that exosomes mediate 
the wide-ranging therapeutic efficacy of stem cells, opens up new therapeutic avenues, which have relevance in the GDM area.

Arguably, as the result of a multidisciplinary and relatively 'new' research field, the precise nomenclature and classification of EVs remains troublesome [62]. The International Society for Extracellular Vesicles (ISEV) encourage the adoption of the term 'EVs' when referring to secreted vesicles [63-65]. In practice, EVs are frequently categorized into heterogeneous EV subsets such as exosomes, microvesicles or apoptotic bodies, based on their perceived route of biogenesis and biophysical characterization (for example, the vesicle diameter). The capacity to uphold one terminology over another remains challenging. In part, this is due to 'crude' EV isolation protocols that often co-isolate non-EV material. To confound this issue, such immature EV isolation methods are often accompanied by incomplete/ 'poor' EV characterization. Therefore, when interpreting EV studies, it is wise to exercise caution and consider the EV isolation method, the EV characterization and subsequent functionality/model/disease employed. EV biogenesis and nomenclature has been extensively reviewed [62]. Henceforth, for the purpose of inter-study interpretation, in this review we will adopt the nomenclature chosen by the cited articles where appropriate.

\subsection{Further Particulars of Exosome Characteristics and Methodologies for Exosome Extraction for Fluid and Exosome Analyses}

Exosomes are 50-160 nM endocytic vesicles (enrichment in HSP 70, tetraspanins, Tsg101, Alix, Major histocompatibility complex (MHC) molecules) limited by a lipid bilayer and characterized by a defined density (flotation at $1.13-1.21 \mathrm{~g} / \mathrm{mL}$ on a sucrose gradient) $[33,66,67]$. According to the current version of the exosome content database, ExoCarta (Version 4, http://www.exocarta.org), 4563 proteins, 194 lipids, 1,639 mRNAs and 764 miRs have been identified in exosomes from a variety of cell types [67-70]. The main components of exosome membranes are lipids and proteins, which are enriched with lipid rafts [32,55,71]. The exosomal lumen has numerous proteins [33], chemokines, such as CCL2, CCL3, CCL4, CCL5, CCL20 and nucleic acids, including mRNAs, miRs and other non-coding RNAs (ncRNAs) $[40,67,72]$, reflecting both the condition and origin of the parent or producer cell [73]. Moreover, an in-depth characterization of proteins common to most exosomes shows that they express tetraspanin proteins CD63, CD9 and CD81 [32,55,56], other membrane-bound proteins and chaperones have also been shown [33,74].

Several methodologies are currently being used to isolate, quantify and validate the exosomes [75-78]. The optimal exosome isolation method depends upon the intended therapeutic use, route of administration, source material (e.g., milk, plasma, urine, cell culture) [79]. Exosome isolation and detection methods have been extensively reviewed in detail [80-86].

\subsection{Exosomal microRNAs}

Exosomes contain a wide range of small RNAs, particularly microRNAs (miRs) but also other forms of small non-coding RNAs (vaultRNA, tRNAs and miRs) [87] and specialized mechanisms are involved in their recruitment and loading to exosomes [88]. In a human, there is in excess of $2000 \mathrm{miRs}$. miRs mediate post-transcriptional gene silencing; to do this a miR mainly binds to the $3^{\prime}$ and untranslated region ( $3^{\prime}$-UTR) of a pool of target messenger RNA (mRNA) [89]. However, miRs can also bind to the mRNA $5^{\prime}$-UTR or open reading frame (ORF) regions $[89,90]$. The involvement of miRs in many biological activities has been well documented, including cell proliferation, cell differentiation, cell migration, disease initiation and disease progression [91-95]. In addition to being packed into exosomes or microvesicles, extracellular miRs can be loaded into lipoproteins $[96,97]$ or bound by AGO-2 protein outside of vesicles [98]. All three modes of action protect miRs from degradation and guarantee their stability during their transportation in body fluids [98-103]. The role of miRs in exosomes is gaining increasing scientific attention. Conveying information via circulating EVs is deemed to be a third way of intercellular communication that is as essential as the cell-to-cell contact-dependent signaling and miR signaling via transfer of soluble molecules [104]. The role of 
exosomal miRs is of great importance in gene expression, demonstrating potential for new therapies and regenerative medicine $[105,106]$. Of note, viral miRs are also present in exosomes produced by infected mammalian cells, representing a new mechanism exploited by human tumor viruses to spread their attack $[107,108]$. This pathogenic mechanism is fascinating and suggests the possible use of exosomes for synthetic RNA-based therapies (discussed below).

\subsection{Clinical Trials to Date, Using Exosome as a Therapy}

Exosomes of autologous or allogenic origin have already been tested in different patient populations with reassuring results in term of safety. The exosomes safety profile depends on the cell from which they were derived [109-114]. Encouragingly, the recent clinical trials using cell-derived exosomes did not report serious adverse reactions thus far $[112,113,115]$. Escudier et al. reported results from the first exosome Phase I trial in 2005, highlighting the feasibility of large-scale exosome production and the safety of exosome administration [115]. More specifically, they used autologous exosomes pulsed with MAGE 3 peptides (of note, MAGE-3 gene is expressed in many tumors but it is silent in normal tissues and antigens encoded by MAGE-3). It therefore may be a useful target for specific anti-tumor immunization of cancer for the immunization of melanoma patients [115]. In the same year, Morse et al. [112], reported their study, which tested the safety, feasibility and efficacy of autologous dendritic cell (DC)-derived exosomes (DEX) loaded with the MAGE tumor antigens in patients with non-small cell lung cancer. They showed that the production of the DEX vaccine was feasible and that DEX therapy was well tolerated in patients with advanced cancer. Some patients experienced long term stabilization of the disease and activation of immune effectors. In 2008, Dai et al. reported the phase I clinical trial of the ascites-derived exosomes (Aex) in combination with the granulocyte-macrophage colony-stimulating factor (GM-CSF) in the immunotherapy of colorectal cancer (CRC), showing that the therapy was safe and well tolerated and induced a beneficial tumor-specific antitumor cytotoxic $\mathrm{T}$ lymphocyte (CTL) response [113]. In the Phase II clinical trial of the use of DEX in non-small cell lung cancer (NSCLC), they are testing the clinical benefit of $\gamma$-Dex (exosomes derived from IFN- $\gamma$-treated DC) as a maintenance immunotherapy in cancer patients at stage IIIB-IV, responding to or stabilized with, cisplatin-based chemotherapy [114]. The study has so far confirmed the capacity of Dex to boost the NK cell arm of antitumor immunity in patients with advanced NSCLC [116]. A Phase I clinical trial using DEX to treat advanced melanoma illustrated that Dex treatment enhanced the proportion and absolute number of circulating NK cells and restored the expression of a type II transmembrane receptor Natural Killer Group 2 member D (NKG2D), which is expressed on circulating T and NK cells [117], thus stimulating the MHC unrestricted NKG2D dependent cytotoxicity. These data provide a mechanistic explanation on how Dex may stimulate non-MHC restricted-anti-tumor effectors and induce tumor regression in vivo [118].

According to the www.clinicaltrials.gov website [119], there are currently 148 studies listed as clinical trials using exosomes as therapy and/or diagnosis, to study the pathophysiology of the disease and to predict and understand the outcomes after therapy $[119,120]$. From these listed studies, in total only twelve studies (summarized in Table 1) are using exosomes in innovative therapeutic approaches. 
Table 1. Current clinical trials testing the therapeutic potential of exosomes from several sources in different human diseases.

\begin{tabular}{|c|c|c|c|}
\hline Exosomes Type & Condition to Be Treated & Locations & Reference \\
\hline $\begin{array}{l}\text { CAP-1002 (Cardiosphere-Derived } \\
\text { Cells: CDCs) }\end{array}$ & Duchenne muscular dystrophy & $\begin{array}{l}\text { Multicenter American Study } \\
\text { (California, Florida, Missouri, } \\
\text { Ohio, Utah, Wisconsin) }\end{array}$ & [121] \\
\hline $\begin{array}{l}\text { Curcumin conjugated with } \\
\text { plant exosomes }\end{array}$ & Colon cancer & University of Louisville, USA & [122] \\
\hline Ginger and aloe plants exosomes & Polycystic ovary syndrome & $\begin{array}{l}\text { University of Louisville } \\
\text { Louisville, Kentucky, USA }\end{array}$ & [123] \\
\hline DEX & Cancer vaccination to lung cancer & $\begin{array}{l}\text { Gustave Roussy, Cancer Campus, } \\
\text { Grand Paris }\end{array}$ & [124] \\
\hline $\begin{array}{l}\text { MSC-derived exosomes with } \\
\text { KrasG12D siRNA ("iExosomes") }\end{array}$ & Pancreatic cancer & $\begin{array}{l}\text { M.D. Anderson Cancer } \\
\text { Center, USA }\end{array}$ & [125] \\
\hline MSC Exo $^{\text {Exo }}$ & $\begin{array}{l}\text { Healing of large and refractory } \\
\text { macular holes }\end{array}$ & $\begin{array}{l}\text { Tianjin Medical University Eye } \\
\text { Hospital (China) }\end{array}$ & [126] \\
\hline $\begin{array}{l}\text { MSC derived microvesicles } \\
\text { and exosomes }\end{array}$ & Type I Diabetes Mellitus & $\begin{array}{l}\text { General Committee of Teaching } \\
\text { Hospitals and Institutes, Egypt }\end{array}$ & [127] \\
\hline $\begin{array}{l}\text { Umbilical mesenchymal stem cells } \\
\text { derived exosomes }\end{array}$ & $\begin{array}{l}\text { Dry eye symptoms in patients } \\
\text { with chronic Graft Versus Host } \\
\text { Diseases (cGVHD) }\end{array}$ & $\begin{array}{l}\text { Zhongshan Ophthalmic Center, } \\
\text { Sun Yat-sen University, China. }\end{array}$ & [128] \\
\hline $\begin{array}{l}\text { Exosomes derived from amniotic } \\
\text { liquid stem cell }\end{array}$ & Depression, anxiety and dementia & $\begin{array}{l}\text { Neurological Associates of West } \\
\text { Los Angeles, USA }\end{array}$ & [129] \\
\hline $\begin{array}{l}\text { Exosome produced from neonatal } \\
\text { stem cell }\end{array}$ & Craniofacial neuralgia & $\begin{array}{l}\text { Neurological Associates of West } \\
\text { Los Angeles, USA }\end{array}$ & [130] \\
\hline MSC $^{\text {Exo }}$ enriched by miR-124 & $\begin{array}{l}\text { Disability of patients with acute } \\
\text { ischemic stroke }\end{array}$ & $\begin{array}{l}\text { Isfahan University of Medical } \\
\text { Sciences, Iran }\end{array}$ & [131] \\
\hline Stem cell conditioned medium & Chronic ulcer wounds [12] & $\begin{array}{l}\text { Stem Cell and Cancer Institute, } \\
\text { Kalbe Farma TbkPT Pharma } \\
\text { Metric Labs, Indonesia. }\end{array}$ & [132] \\
\hline Human MSC-exosomes & Bronchopulmonary dysplasia & United Therapeutics USA. & [119] \\
\hline
\end{tabular}

\subsection{Exosomes as a Drug delivery System}

As previously indicated, exosomes are a cell-free natural system for ferrying functionally active RNA between cells. Their membranes protect the RNA from degradation and supposedly contain recognition systems (not yet sufficiently elucidated) allowing them to target recipient cells. This process possibly inspired the idea that synthetic small RNAs, such as small interfering RNA (siRNAs) $[133,134]$, can be delivered by exosomes mimicking the molecular mechanism of endogenous miRs transportation [71]. In support, Wahlgren et al. used plasma exosomes as gene delivery platforms to transfer siRNAs and silence MAPK in monocytes and lymphocytes [135]. Moreover, Wahlgren et al., 2012 and Alexander et al., 2015, showed that exosome-delivered exogenous miRs can re-program the cellular response to endotoxin, where exosome-delivered miR-155 enhances while miR-146a reduces inflammatory gene expression $[135,136]$. Overall, these studies provide evidence that exosomes have the potential to regulate inflammatory response. Expanding from this, exosomes can represent an efficient vehicle for acidic nucleic therapies [135]. Recombinant adeno-associated virus (rAAV) vectors are sized about $20 \mathrm{~nm}$ (hence can fit into exosomes) and are considered promising vectors for gene therapies for the cardiac and skeletal muscles $[137,138]$. rAAV became the first clinically approved gene therapy product in the western world [139]. In contrast to the near absence of a cellular immune response against rAAVs, clinical trials have shown that pre-existing neutralizing antibodies act against the naturally occurring AAV serotypes (presumably, a result of a prior infection with wild-type AAVs) in more than half the patients; this represents a significant obstacle to the broad application of AAV gene therapy [138]. Exosomes could help and overcome this issue. During rAAV production, a fraction of AAV vectors are embedded in exosome and microvesicles. The "vexosomes" (vector-exosomes) can 
outperform conventionally purified AAV vectors in transduction efficiency [140] and evade human neutralizing anti-AAV antibodies. Moreover, they can be modified to express a tissue/cell targeting peptide on the exosome external membrane, to improve delivery specific areas [139].

Further studies have shown that exosome-based drug delivery systems may provide unique advantages, including limited or no undesired immunogenicity when self-derived exosomes are used, greater stability in the blood due to evasion of complement and coagulation factors, efficient delivery of cargo into the cytosol of the target cell and possibly fewer off-target effects due to the natural tendency of exosomes to act on specific target cells [141,142]. An encouraging example is that the intranasal administration of curcumin-enriched exosomes (Exo-cur) led to rapid delivery of an exosome encapsulated drug to the brain that was selectively taken up by microglial cells to subsequently induce their apoptosis. These results demonstrate that this strategy may provide a non-invasive and novel therapeutic approach for treating inflammatory-related diseases, even in less accessible organs such as the brain [143]. To incorporate drugs into exosomes, different possibilities have been suggested [144]. Lipophilic small molecules were passively loaded into exosomes during co-incubation with exosomes $[145,146]$.

MSCs are easily harvested from a large variety of human tissues including those that can often be considered 'medical waste' such as: adipose tissue [147,148], liver [149], muscle [150], amniotic fluid [151], placenta [152,153], umbilical cord blood [147], dental pulp [154,155], human ESC [156] and other sources. MSCs have shown a scalable ability to mass-produce exosomes, which is a highly desired attribute for conversion of MSC-exosomes into drug delivery vehicles [157]. MSCs therefore represent suitable cell candidates for the mass production of exosomes for drug delivery. Moreover, there are also alternative sources for large-scale production of drug-enriched exosomes with low host immunogenicity. For example, bovine milk exosomes were shown to increase oral bioavailability, improve drug efficacy and safety and exhibit tolerance between species without adverse immune and inflammatory response [158].

In summary, exosomes represent an innovative and very promising drug delivery system and exosome -based therapeutics offer new hopes to satisfied unmet clinical needs.

\section{Exosomes and miRs in GDM}

As a consequence of the diverse functions that exosomes undertake, they can be an extremely important tool not only for studying the pathophysiology of GDM but also for a safer, more effective and personalized potential therapy. In this section we will highlight the advances in exosomes studies in GDM and the perspectives for their use in GDM biomarkers and therapy.

Saker et al. showed that the plasma concentration of exosomes is higher in normal pregnant women than in non-pregnant women [159] while a later study from Salomon et al. demonstrated that placental exosomes are released into the maternal circulation at the beginning of 6 weeks of gestation [160]. Interestingly, changes in maternal plasma exosome concentration compared with normal pregnancy has been detected in GDM women [160,161]. Nakahara et al. [162], investigated the profile of placental-derived exosomes (PdE) in a stratified cohort study based on normal $(n=30)$, $\operatorname{GDM}(n=10)$ and preeclampsia $(P E)$ pregnancy $(n=15)$ outcomes. They found that significant factors contributing to total variations of the PdE were gestational age and pregnancy outcomes, PdE levels increased in all types of gestation but in pregnancies complicated by GDM and PE these levels were significantly higher than in normal pregnancies. In addition, maternal body mass index (BMI), glucose concentration and fetal body weight significantly correlated with the concentration of PdE across gestation, suggesting that exosomes may be involved in maternal metabolic adaptation to pregnancy and therefore that PdE may be used as early predictor of adverse outcomes, including GDM and PE [162]. Salomon et al. described that PdE released from women with GDM may alter maternal physiology by a process of exosomal placento-maternal transfection a "payload" of receptors, proteins and/or oligonucleotides, that have been specifically pre-conditioned by the GDM placenta. The authors propose that some mediators act in this system, including the vascular, pancreatic and adipose tissues 
and innate immune response system [163]. They also describe paracellular effects associated with GDM mediated by trophoblasts or placental mesenchymal stem cells (MSCs), altering for example the endothelial activity promoting changes in transport glucose GLUT 3 and thus delivery of energy substrates to the fetus [163]. In addition, PdE may contribute to the proinflammatory state associated with pregnancy, an increased phenomenon under diabetic conditions [26,52]. Jayabalan et al. by using a bioinformatic analysis tool named Sequential Windowed Acquisition of All Theoretical Mass Spectra [SWATH] showed that exosomal proteins are primarily associated with energy production, inflammation and metabolism [164], major pathways compromised by GDM. The data may be of utility in elucidating the underlying physiological mechanisms associated with insulin resistance in GDM [165]. Another study suggests that in GDM, exosomes secreted from adipose tissue regulate placental glucose metabolism by improving the communication of adipose tissue derived exosomes (exo-AT) to placental tissues, this therefore might become an effective intervention strategy to prevent the consequences of GDM, such as fetal overgrowth $[66,164]$. Novel findings indicate that the insulin resistance (IR) observed in obesity is maintained by adipose tissue by releasing exosomes promoting IR and other obesity-related metabolic conditions [166]. These findings support the hypothesis that dysregulated secretion of adipose tissue-derived exosomes plays a pivotal role in the development of GDM in obese mothers [166]. To complement clinical investigations, in vitro studies demonstrated that high D-glucose increases the release of exosomes from first trimester trophoblast cells cytokines secretion, such as interleukin-8 (IL-8) and TNF-a from human umbilical vein endothelial cells (HUVECs), which are of fetal origin [51,167].

Importantly, Salomon et al., 2016, reported that higher concentrations of placental exosomes during early pregnancy (i.e., 11-14 weeks) are predictive of GDM [161] and that the circulating levels of both placental-derived and total exosomes are higher compared with normal pregnancy. However, the ratio between Placental Alkaline Phosphatase (PLAP)/placenta and total exosomes was decreased in the circulation of GDM mothers, which could be explained by the increased release of exosomes from non-placental sources [52,161]. Further studies are needed to investigate exosomes released from non-placental sources such as skeletal muscle and adipose tissue [161].

The study of exosomes as paracrine vectors might generate new knowledge for deciphering GDM pathophysiology for mother and fetus as well as providing precious biomarkers for the prediction and monitoring of the disease. Recently, studies on exosomal miRs provided an opportunity for a better understanding of the molecular processes of skeletal muscle diseases [168-175]. Research suggests that miRs play important roles in skeletal muscle development and several miRs have been identified as biomarkers for myogenesis, muscle mass changes and nutrient metabolism in physiological and pathological states [26,176-178]. Nair et al., 2018 found that placental exosomes in GDM carry a specific set of miRs associated with skeletal muscle insulin sensitivity [26]. The expression of this set of specific exosomal miRs, varied in a consistent pattern in the placenta, in circulating exosomes and in skeletal muscle in GDM. Placental exosomes from GDM pregnancies decreased insulin-stimulated migration and glucose uptake in primary skeletal muscle cells obtained from patients with normal insulin sensitivity. Interestingly, placental exosomes from NGT increase glucose uptake in response to insulin in skeletal muscle from diabetic subjects. These findings suggest that placental exosomes may have a role in modifying insulin sensitivity in normal and GDM pregnancies [161]. These results pave the way for a better understanding of gestational diabetic myopathy and UI in this population with GMD and for clarifying relevant aspects about insulin interaction with the muscle and muscle function.

Several studies suggest that miRs are involved in processes that contribute to the development and evolution of GDM. Dicer and Drosha are important for the miR biogenesis. Rahimi et al. found the dysregulation of Drosha, Dicer in pregnant and GDM patients when compared to healthy controls. They hypothesized that miRs are involved in the development of GDM [179]. Wander et al. found that circulating early-mid-pregnancy miRs are associated with GDM, particularly among overweight/obese women who are pregnant with male offspring [180]. Pillar et al. showed that miRs are involved in the pathogenesis of preeclampsia and GDM and have potential as early biomarkers for disease 
development [54]. Cao et al. concluded that plasma mRNA-16-5p, -17-5p and -20a-5p are potential diagnostic biomarkers in GDM [181]. Li et al. identified a miRNA signature involvement in GDM which may contribute to macrosomia through enhancing epidermal growth factor receptor (EGFR) signaling [182].

Another study demonstrated that the increase in the placenta-enriched miR (miRNA-518d) may contribute to the pathology of the development of GDM, via an effect on the regulation of proliferator-activated receptor- $\alpha$ (PPAR $\alpha$ ) expression [183]. miRs from adipose tissue, such as miR-222, might be a candidate biomarker and therapeutic target for GDM, due to the potential regulation of ER $\alpha$ expression in estrogen-induced insulin resistance in GDM [184]. Exosomal miRs can be profiled in biomarker discovery studies [185]. Trophoblast/cytotrophoblast cells compose the placenta. Consequently, the miRs contained in PdE might help to better define the mechanisms underlining fetal-maternal interaction $[77,186]$ as well as to study placental dysfunction. These PdE-miRs might play an important role in GDM pathogenesis. Therefore, via the study of these exosomal miRs, important aspects could be better understood and explored for more effective future diagnoses and new therapeutic approaches to GDM [53].

\section{Novel Therapeutic Approaches in Gestational Diabetes Mellitus}

During the past decade, stem cell therapy studies have focused on the use of multipotent adult stem cells, particularly mesenchymal stem/stromal cells (MSC), which we will discuss in more depth below. These studies have highlighted new therapeutic promises for a treatment of a variety of conditions including UI and CVDs [187-190]. However, the clinical success of cell therapy has not yet been confirmed in large human studies. Furthermore, animal studies have delivered the knowledge that beneficial pro-regenerative and anti-inflammatory effects of stem cell therapies are mediated by a paracrine action and/or by acute immune response to cell delivery rather than an in situ transdifferentiation [191,192].

MSCs can be extracted from different sources, including the bone marrow, amniotic fluid [151] and placenta [193] and possess tissue protective and regenerative attributes together with immunomodulatory, anti-inflammatory, proangiogenic and antifibrotic capacities. Recent studies have established that one of the main therapeutic vectors of MSCs is represented by EVs, particularly exosomes [194]. However, the mechanisms by which MSC-exosomes afford their beneficial actions remain incompletely understood. Several studies suggest that MSC-exosomes regulate immune responses [195,196]; reinforcing this proposition, recent data suggests that macrophage (MФ) immunomodulation is the 'gatekeeper' to the success of MSC-exosome therapies [197,198]. MSC-exosomes reportedly modulate $M \Phi$ phenotype, suppressing the proinflammatory M1-like state and shifting the M2-like M $\Phi$ to favor an anti-inflammatory, pro-regulatory phenotype both in vitro and in vivo $[197,198]$. However, exosomes extracted from cells cultured in cardiometabolic disease [199-205] mimicking conditions or from biological fluids of diabetic patients, produce pathogenic microangiopathic effects [201,202]. Taken together, extreme caution should be exercised when considering the use of 'naïve' patient-derived exosomes for therapeutic intervention. In contrast, several reports indicate that allogenic "healthy" MSCs are an excellent source of bioactive exosomes [203], endowed with protective, antifibrotic and proangiogenic properties [204]. Additionally, MSCs reportedly recruit $\mathrm{CCR} 2+$ monocytes $(\mathrm{Mo})$, which were shown to contribute to the regenerative properties induced by stem cell injection into the rodent heart [192,205]. Although great success has already been achieved using cell therapy with mesenchymal stem cell (MSC), many aspects related to their effectiveness and side effects need to be deciphered, including their potential carcinogenicity $[79,206,207]$ as well as their migratory ability (to different sites) and the resulting engraftment potential [208-210]. These challenges become even bigger in GDM treatment through stem cell therapy, as there is a major limitation on the safety of therapy in this case, to avoid deleterious effects that might reach the conceptus. 
For these reasons new acellular approaches to therapy have been employed in recent years as a basis for the knowledge gained about on the paracrine action of MSCs through exosomes and their important biological role in the body $[207,211]$.

Therapies based on MSC-exosomes represent a promising scientific field to be tested for the capacity to improve the post-GDM outcome of mother and child. Exosomes have a good potential for protective and regenerative therapies and in GDM-caused myopathy, they could be delivered locally for example by (co-injection, mixing with hydrogels or coating scaffolds with exosomes using fibrin gels or specific linkers) [212].

Interestingly, human adipose-derived stem cell (hADSCs)-exosomes showed some promise to contrast stress urinary incontinence (SUI), a common medical condition affecting approximately $30 \%$ of postpartum women [213]. Specifically, Ni et al. found that administration of hADSCs-exosomes provided functional and histological improvements in a rodent model of SUI [213]. In addition, they found hADSCs-exosomes harbored several proteins associated with PI3K-Akt, Jak-STAT and Wnt signaling pathways, that were associated with skeletal muscle and nerve regeneration and proliferation improving the SUI [213]. In accordance, Liu et al. found that hADSCs-exosomes increased type I collagen content by increasing collagen synthesis and decreasing collagen degradation in vaginal fibroblasts from women with SUI, supporting the notion that these exosomes may be a novel therapeutic approach for treating SUI [214]. More recent work from the same research group also showed that exosomes secreted by fibroblasts from women with SUI play an important role in regulating endothelial cell angiogenesis [215].

Interestingly, $\mathrm{Wu}$ et al. showed that exosomes derived from stem cells contained in the urine (USCs-Exo) can improve skeletal muscle regeneration in pubococcygeus muscle injury in rats [216]. Here, the authors found that USC-Exos act on satellite cells promoting their activation, proliferation and differentiation via an enhancement of the phosphorylation of extracellular-regulated protein kinases (ERK). This paper has therefore identified a novel agent for skeletal muscle regeneration providing a basis for further exploring a cell-free correction for SUI [216]. Notably, GDM is associated with other comorbidities such as gestational hypertension (HTN), hypothyroidism, obesity and lipid abnormalities, which can become chronic throughout the woman's life [217-219]. On balance, exosomes hold promise as a novel therapeutic approach for pathologies associated with GDM.

The use of exosomes as therapy for GDM outcomes, such as UI and CVD are still premature but encouraging in vitro and preclinical results provide promise. Table 2 shows an overview of the potential of exosomes in protective regenerative medicine in the context of GDM [212,220]. 
Table 2. Overview of the characteristics of mesenchymal stem cell (MSC) exo $^{\text {ex }}$ that suggest their potential in gestational diabetes mellitus (GDM) treatment.

\begin{tabular}{|c|c|c|}
\hline Biological Process & Effects & Reference \\
\hline Angiogenesis/Cell proliferation & $\begin{array}{l}\text { Proliferation, migration and tube formation of endothelial cells through the } \\
\text { Wnt } 4 / \beta \text {-Catenin Pathway/ } \\
\text { Transferring miR), tube formation into endothelial cells miR-135b and by } \\
\text { targeting factor-inhibiting HIF-1/ } \\
\text { Promotes the enhancement of the proliferation and migration of fibroblasts by } \\
\text { transferring signals to target cells activating several signaling important pathways } \\
\text { (Akt, ERK and STAT3) and inducing the expression of a number of growth factors - } \\
\text { [hepatocyte growth factor (HGF), insulin-like growth factor-1 (IGF1), nerve growth } \\
\text { factor (NGF) and stromal-derived growth factor-1 (SDF1)]/ } \\
\text { Inducing neovascularization in preclinical models by the paracrine effect by } \\
\text { transferring pro-angiogenic microRNAs / } \\
\text { Endothelial cell angiogenesis by transferring miR-125a/ }\end{array}$ & [221-225] \\
\hline Immunomodulation & $\begin{array}{l}\text { Immunomodulatory effect of human stimulated T cells by inhibitory effect in the } \\
\text { differentiation and activation of T cells as well as a reduced T cell proliferation } \\
\text { and IFN- } \gamma \text { release/ } \\
\text { Modulation of the local and systemic maternal immune system by exosomes secreted } \\
\text { from trophoblast cells that carry HLA-G and B7 family immunomodulators/ } \\
\text { MSC-derived exosome possesses the immunomodulatory properties mediated by } \\
\text { paracrine factors suppressing the secretion of pro-inflammatory factor TNF-a and } \\
\text { IL-1b, increasing TGF- } \beta \text {, inducing the conversion of T helper type } 1 \text { into T helper } \\
\text { type } 2 \text { also reducing the potential of T cells to differentiate into IL 17/ } \\
\text { Exosomes are the trigger the release of cytokines/chemokines from immune cells and } \\
\text { stimulation of anti-tumor immune reactions or in a systemic immunosuppression by } \\
\text { inducing the secretion of pro-inflammatory cytokines such as IL-1 } \beta \text {, tumor necrosis } \\
\text { factor (TNF)- } \alpha \text {, IL-23a, CCL5 (RANTES) and IL-6/ } \\
\text { Exosomes from MSCs ameliorate experimental } \\
\text { bronchopulmonary dysplasia and restore lung function through } \\
\text { M } \Phi \text { immunomodulation by suppressing the pro-inflammatory "M1" state and } \\
\text { augmenting an anti-inflammatory “M2-like via Cytokines, such as Ccl2, Ccl7 and IL6/ } \\
\text { MSC exosomes enhanced the survival of allogenic skin graft in mice by induced } \\
\text { polymyxin-resistant by activating APCs via MyD88-dependent. }\end{array}$ & {$[198,226-230]$} \\
\hline
\end{tabular}

\section{Concluding Remarks}

Once the scientific community has fully succeeded in harnessing the beneficial properties of exosomes, unlocking their potential for drug delivery and the correction of gene expression in specifics cells and tissues, they could become powerful and sophisticated tools, in the emerging field of nanomedicine (summarized in Figure 1). Improving fundamental knowledge on exosome structure, biogenesis, roles in cell-to-cell signaling, the process of recognition and internationalization of exosomal content all combined, should allow further improvement of the methods to manipulate the exosome cargo and then deliver it in a very precise and effective way. However, as illustrated above, there are still a number of important challenges to be addressed, such as dosage and route of application to obtain desired therapeutic effects, tracking of exosomes in the body in target cells or tissues, as well as the long-term evaluation of side effects that therapy may cause. Investigation of the maternal plasma exosomes concentration and molecular content might add important knowledge to the understanding of the GDM etiology and complications on mother and child and then be translated into diagnostic and predictive biomarkers in a clinical context. 


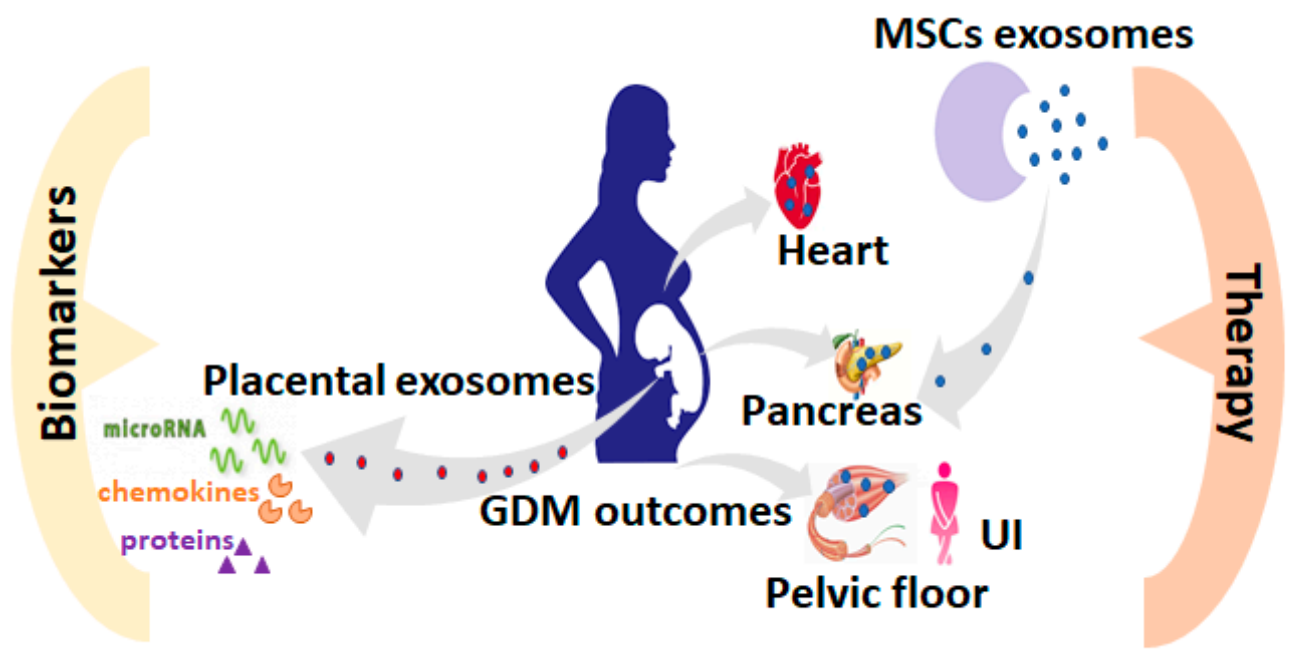

Figure 1. Overview of the potential impact of exosome in GDM. The therapeutic approach is shown on the right side: "Therapeutic" exosomes (from mesenchymal stem/stromal cells or alternative sources) could be used to reduce the negative impact of GDM on cardiovascular disease (exemplified by the heart in the figure), diabetes mellitus (simplified by the pancreas) and on the myopathy of pelvic floor and rectus abdominis muscle, which contribute to urinary incontinence (UI) up to 2 years postpartum. The diagnostic approach is shown on the left side: Through the exosomal content profile, new biomarkers of GDM onsets (diagnostic biomarkers) and post-GDM negative outcome (diagnostic and prognostic biomarkers) could be developed to improve the treatment of the GDM and the outcome for the mother and child.

Author Contributions: J.F.F. collected literature resources and wrote the first draft; G.W. advised on new parts to be input in the manuscript and revised the manuscript; F.C. wrote a part of the draft; M.V.C.R. provided financial support and reviewed the manuscript, P.R.d.L. searched bibliography. F.V.D.S.R., A.M.P.B. and C.E. co-wrote the draft and provided supervision and financial support. All authors have read and agreed to the published version of the manuscript.

Funding: This research was funded by São Paulo Research Foundation (FAPESP) fellowship number 2019/02405-4) (to J.F.F.); FAPESP-Imperial Global Engagement Scheme (SPRINT) award (to C.E. and M.V.C.R); Research England Global Challenges Research Fund (QR GCRF, to C.E.); British Heart Foundation: Programme grant (RG/15/5/31446, to C.E.), Chair Award (CH/15/1/31199, to C. E.) and Centre of Vascular Regeneration (BHF-CVR2, to C. E.). National Council for Scientific and Technological, CNPq (409902/2018-7) (to M.V.C.R.)

Acknowledgments: We are thankful to Jeremy C Hill (Imperial College London) for editorial assistance. J.F.F., A.M.P.B. and M.V.C.R. are part of the Diamater Research group. The laboratory of C.E. is part of the European COST action. CA17129-Catalysing transcriptomics research in cardiovascular disease.

Conflicts of Interest: The authors declare no conflict of interest.

$\begin{array}{ll}\text { Abbreviations } & \\ \gamma-\text { Dex } & \text { exosomes derived from IFN- } \gamma \text {-treated DC } \\ \text { AAV } & \text { adeno-associated virus } \\ \text { Aex } & \text { ascites-derived exosomes } \\ \text { BCa } & \text { breast cancer } \\ \text { BMI } & \text { body mass index } \\ \text { Ca } & \text { calcium } \\ \text { CDCs } & \text { cardiosphere-derived cells } \\ \text { CGVHD } & \text { chronic Graft Versus Host Diseases } \\ \text { CRC } & \text { colorectal cancer } \\ \text { CSF } & \text { colony-stimulating factor } \\ \text { CTL } & \text { cytotoxic T lymphocyte } \\ \text { CVD } & \text { cardiovascular diseases } \\ \text { DC } & \text { dendritic cell }\end{array}$




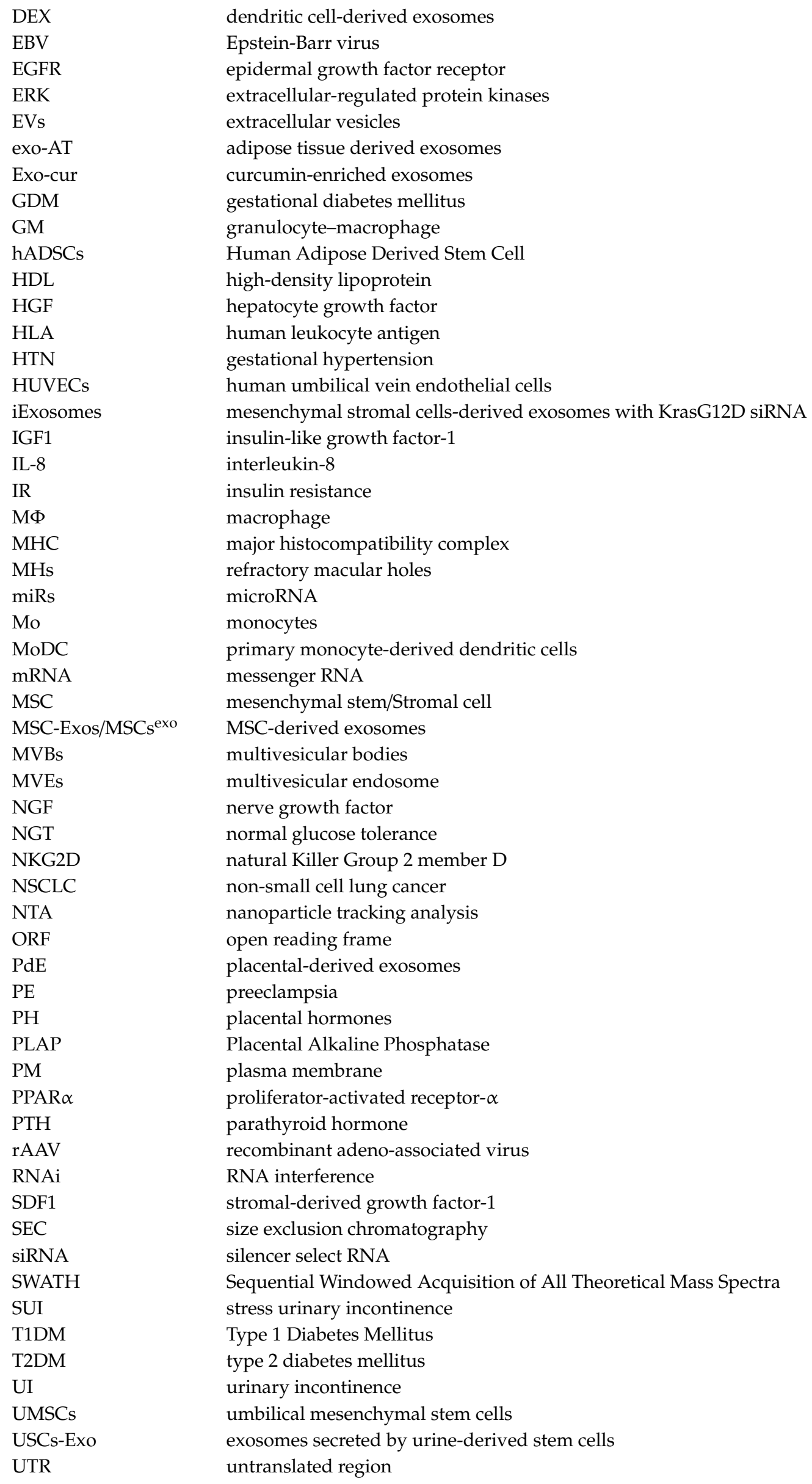




\section{References}

1. Whiting, D.R.; Guariguata, L.; Weil, C.; Shaw, J. IDF Diabetes Atlas: Global estimates of the prevalence of diabetes for 2011 and 2030. Diabetes Res. Clin. Pract. 2011. [CrossRef] [PubMed]

2. Rich-Edwards, J.W.; McElrath, T.F.; Karumanchi, S.A.; Seely, E.W. Breathing life into the lifecourse approach: Pregnancy history and cardiovascular disease in women. Hypertension 2010, 56, 331-334. [CrossRef]

3. Kim, C.; Newton, K.M.; Knopp, R.H. Gestational Diabetes and the Incidence of Type 2 Diabetes. Diabetes Care 2002, 25, 1862-1868. [CrossRef]

4. Bellamy, L.; Casas, J.P.; Hingorani, A.D.; Williams, D. Type 2 diabetes mellitus after gestational diabetes: A systematic review and meta-analysis. Lancet 2009, 373, 1773-1779. [CrossRef]

5. Sullivan, S.D.; Umans, J.G.; Ratner, R. Gestational diabetes: Implications for cardiovascular health. Curr. Diab. Rep. 2012, 12, 43-52. [CrossRef] [PubMed]

6. Retnakaran, R. Hyperglycemia in pregnancy and its implications for a woman's future risk of cardiovascular disease. Diabetes Res. Clin. Pract. 2018, 145, 193-199. [CrossRef]

7. Marathe, P.H.; Gao, H.X.; Close, K.L. American Diabetes Association Standards of Medical Care in Diabetes 2017. J. Diabetes. 2017, 9, 320-3244. [CrossRef]

8. Barbosa, A.M.P.; Dias, A.; Marini, G.; Calderon, I.M.P.; Witkin, S.; Rudge, M.V.C. Urinary incontinence and vaginal squeeze pressure two years post-cesarean delivery in primiparous women with previous gestational diabetes mellitus. Clinics 2011, 66, 1341-1345.

9. Chuang, C.M.; Lin, I.F.; Horng, H.C.; Hsiao, Y.H.; Shyu, I.L.; Chou, P. The impact of gestational diabetes mellitus on postpartum urinary incontinence: A longitudinal cohort study on singleton pregnancies. BJOG Int. J. Obstet. Gynaecol. 2012, 119, 1334-1343. [CrossRef]

10. Kim, C.; McEwen, L.N.; Sarma, A.V.; Piette, J.D.; Herman, W.H. Stress urinary incontinence in women with a history of gestational diabetes mellitus. J. Women's Heal. 2008, 7, 783-792. [CrossRef]

11. Wilson, L.; Brown, J.S.; Shind, G.P.; Luca, K.O.; Subak, L.L. Annual direct cost of urinary incontinence. Obstet. Gynecol. 2001, 98, 398-406. [PubMed]

12. Alvarenga-Martins, N.; Pinto, P.F.; Arreguy-Sena, C.; Campos Paschoalin, H.; Alves de Moura, D.C.; Vasconcelos Teixeira, C. Urinary Incontinence: An Analysis in the Perspective of Aging Policies. J. Nurs. UFPE / Rev. Enferm. UFPE 2017, 11, 1189-1199.

13. Anger, J.T.; Saigal, C.S.; Madison, R.; Joyce, G.; Litwin, M.S. Increasing Costs of Urinary Incontinence Among Female Medicare Beneficiaries. J. Urol. 2006, 176, 247-251. [CrossRef]

14. Segedi, L.M.; Ilić, K.P.; Curcić, A.; Visnjevac, N. Quality of life in women with pelvic floor dysfunction. Vojnosanit. Pregl. 2011, 68, 940-947. [CrossRef] [PubMed]

15. Sun, Z. Muscular response and adaptation to diabetes mellitus. Front. Biosci. 2008, 13, 4765-4794. [CrossRef]

16. Jellinger, P.S. Metabolic consequences of hyperglycemia and insulin resistance. Insulin 2009, 4, 2-14. [CrossRef]

17. Alperin, M.; Lawley, D.M.; Esparza, M.C.; Lieber, R.L. Pregnancy-induced adaptations in the intrinsic structure of rat pelvic floor muscles. Am. J. Obstet. Gynecol. 2015, 213, e1-e7. [CrossRef]

18. Alperin, M.; Kaddis, T.; Pichika, R.; Esparza, M.C.; Lieber, R.L. Pregnancy-induced adaptations in intramuscular extracellular matrix of rat pelvic floor muscles. Am. J. Obstet. Gynecol. 2016, 215, e1-e7. [CrossRef]

19. Piculo, F.; Marini, G.; Barbosa, A.M.P.; Damasceno, D.C.; Matheus, S.M.M.; Felisbino, S.L.; Daneshgari, F.; Rudge, M.V.C. Urethral striated muscle and extracellular matrix morphological characteristics among mildly diabetic pregnant rats: Translational approach. Int. Urogynecol. J. 2014, 25, 403-415. [CrossRef]

20. Marini, G.; Piculo, F.; Vesentini, G.; Barbosa, A.M.P.; Damasceno, D.C.; Matheus, S.M.M.; Hijaz, A.; Daneshgari, F.; Rudge, M.V.C. Effects of short-term severe and long-term mild STZ-induced diabetes in urethral tissue of female rats. Neurourol. Urodyn. 2017, 36, 574-579. [CrossRef]

21. Liu, G.; Daneshgari, F. Temporal diabetes- and diuresis-induced remodeling of the urinary bladder in the rat. Am. J. Physiol. Regul. Integr. Comp. Physiol. 2006, 291, R837-R843. [CrossRef]

22. Marini, G.; Piculo, F.; Vesentini, G.; Damasceno, D.C.; Delella, F.K.; Calderon, I.M.P.; Daneshgari, F.; Felisbino, S.L.; Barbosa, A.M.P.; Rudge, M.V.C. The influence of hyperglycemia on the remodeling of urethral connective tissue in pregnant rats. Eur. J. Obstet. Gynecol. Reprod. Biol. 2018, 221, 81-88. [CrossRef] [PubMed] 
23. D'Souza, D.M.; Al-Sajee, D.; Hawke, T.J.; Guimarães-Ferreira, L.; Spangenburg, E.; Hermano, C.; Pinheiro, J.; Berdeaux, R. Diabetic myopathy: Impact of diabetes mellitus on skeletal muscle progenitor cells. Front. Physiol. 2013, 4, 1-7.

24. Asemi, Z.; Karamali, M.; Esmaillzadeh, A. Effects of calcium-vitamin D co-supplementation on glycaemic control, inflammation and oxidative stress in gestational diabetes: A randomised placebo-controlled trial. Diabetologia 2014, 57, 1798-1806. [CrossRef] [PubMed]

25. Karamali, M.; Alselmi, Z.; Ahmad-Dastjerdi, M.; Esmaillzadeh, A. Calcium plus vitamin D supplementation affects pregnancy outcomes in gestational diabetes: Randomized, double-blind, placebo-controlled trial. Public Health Nutr. 2016, 19, 156-163. [CrossRef] [PubMed]

26. Nair, S.; Jayabalan, N.; Guanzon, D.; Palma, C.; Scholz-Romero, K.; Elfeky, O.; Zuñiga, F.; Ormazabal, V.; Diaz, E.; Rice, G.E.; et al. Human placental exosomes in gestational diabetes mellitus carry a specific set of miRNAs associated with skeletal muscle insulin sensitivity. Clin. Sci. 2018, 132, 2451-2467. [CrossRef] [PubMed]

27. Jiang, L.Q.; Duque-Guimaraes, D.E.; MacHado, U.F.; Zierath, J.R.; Krook, A. Altered response of skeletal muscle to IL-6 in type 2 diabetic patients. Diabetes 2013, 62, 355-361. [CrossRef]

28. Ramchurn, N.; Mashamba, C.; Leitch, E.; Arutchelvam, V.; Narayanan, K.; Weaver, J.; Hamilton, J.; Heycock, C.; Saravanan, V.; Kelly, C. Upper limb musculoskeletal abnormalities and poor metabolic control in diabetes. Eur. J. Intern. Med. 2009, 20, 718-721. [CrossRef]

29. Aldabe, D.; Ribeiro, D.C.; Milosavljevic, S.; Dawn Bussey, M. Pregnancy-related pelvic girdle pain and its relationship with relaxin levels during pregnancy: A systematic review. Eur. Spine J. 2012, 21, 1769-1776. [CrossRef]

30. Harding, C.V.; Heuser, J.E.; Stahl, P.D. Exosomes: Looking back three decades and into the future. J. Cell Biol. 2013, 200, 367-371. [CrossRef]

31. Pan, B.T.; Johnstone, R.M. Fate of the transferrin receptor during maturation of sheep reticulocytes in vitro: Selective externalization of the receptor. Cell 1983, 33, 967-978. [CrossRef]

32. Simons, M.; Raposo, G. Exosomes-vesicular carriers for intercellular communication. Curr. Opin. Cell Biol. 2009, 21, 575-581. [CrossRef] [PubMed]

33. Théry, C.; Zitvogel, L.; Amigorena, S. Exosomes: Composition, biogenesis and function. Nat. Rev. Immunol. 2002, 2, 569-579. [CrossRef] [PubMed]

34. Harding, C.; Heuser, J.; Stahl, P. Receptor-mediated endocytosis of transferrin and recycling of the transferrin receptor in rat reticulocytes. J. Cell Biol. 1983, 97, 329-339. [CrossRef] [PubMed]

35. Schneider, A.; Simons, M. Exosomes: Vesicular carriers for intercellular communication in neurodegenerative disorders. Cell Tissue Res. 2013, 352, 33-47. [CrossRef]

36. Valadi, H.; Ekström, K.; Bossios, A.; Sjöstrand, M.; Lee, J.J.; Lötvall, J.O. Exosome-mediated transfer of mRNAs and microRNAs is a novel mechanism of genetic exchange between cells. Nat. Cell Biol. 2007, 9, 654-659. [CrossRef]

37. Skog, J.; Würdinger, T.; van Rijn, S.; Meijer, D.H.; Gainche, L.; Curry, W.T.; Carter, B.S.; Krichevsky, A.M.; Breakefield, X.O. Glioblastoma microvesicles transport RNA and proteins that promote tumour growth and provide diagnostic biomarkers. Nat. Cell Biol. 2008, 10, 1470-1476. [CrossRef]

38. Al-Nedawi, K.; Meehan, B.; Micallef, J.; Lhotak, V.; May, L.; Guha, A.; Rak, J. Intercellular transfer of the oncogenic receptor EGFRvIII by microvesicles derived from tumour cells. Nat. Cell Biol. 2008, 10, 619-624. [CrossRef]

39. Pant, S.; Hilton, H.; Burczynski, M.E. The multifaceted exosome: Biogenesis, role in normal and aberrant cellular function and frontiers for pharmacological and biomarker opportunities. Biochem. Pharmacol. 2012, 83, 1484-1494. [CrossRef]

40. Sato-Kuwabara, Y.; Melo, S.A.; Soares, F.A.; Calin, G.A. The fusion of two worlds: Non-coding RNAs and extracellular vesicles - Diagnostic and therapeutic implications (Review). Int. J. Oncol. 2015, 46, 17-27. [CrossRef]

41. Ratajczak, J.; Miekus, K.; Kucia, M.; Zhang, J.; Reca, R.; Dvorak, P.; Ratajczak, M.Z. Embryonic stem cell-derived microvesicles reprogram hematopoietic progenitors: Evidence for horizontal transfer of mRNA and protein delivery. Leukemia 2006, 20, 847-856. [CrossRef] [PubMed]

42. Wang, H.; Wang, B. Extracellular vesicle microRNAs mediate skeletal muscle myogenesis and disease (Review). Biomed. Rep. 2016, 5, 296-300. [CrossRef] [PubMed] 
43. Raposo, G.; Nijman, H.W.; Stoorvogel, W.; Leijendekker, R.; Harding, C.V.; Melief, C.J.M.; Geuze, H.J. B lymphocytes secrete antigen-presenting vesicles. J. Exp. Med. 1996, 183, 1161-1172. [CrossRef] [PubMed]

44. Del Conde, I.; Shrimpton, C.N.; Thiagarajan, P.; López, J.A. Tissue-factor-bearing microvesicles arise from lipid rafts and fuse with activated platelets to initiate coagulation. Blood 2005, 106, 1604-1611. [CrossRef] [PubMed]

45. El Andaloussi, S.; Mäger, I.; Breakefield, X.O.; Wood, M.J.A. Extracellular vesicles: Biology and emerging therapeutic opportunities. Nat. Rev. Drug Discov. 2013, 12, 347-357. [CrossRef] [PubMed]

46. Rak, J.; Guha, A. Extracellular vesicles - vehicles that spread cancer genes. BioEssays 2012, 34, $489-497$. [CrossRef]

47. Kalluri, R. The biology and function of exosomes in cancer. J. Clin. Investig. 2016, 126, 1208-1215. [CrossRef]

48. Mack, M.; Kleinschmidt, A.; Brühl, H.; Klier, C.; Nelson, P.J.; Cihak, J.; Plachý, J.; Stangassinger, M.; Erfle, V.; Schlöndorff, D. Transfer of the chemokine receptor CCR5 between cells by membrane-derived microparticles: A mechanism for cellular human immunodeficiency virus 1 infection. Nat. Med. 2000, 6, 769-775. [CrossRef]

49. Vella, L.J.; Sharples, R.A.; Lawson, V.A.; Masters, C.L.; Cappai, R.; Hill, A.F. Packaging of prions into exosomes is associated with a novel pathway of PrP processing. J. Pathol. 2007, 211, 582-590. [CrossRef]

50. Jia, R.; Li, J.J.Y.Z.; Rui, C.; Ji, H.; Ding, H.; Lu, Y.; De, W.; Sun, L.; Ilekis, J.V.; Tsilou, E.; et al. Multicolor flow cytometry and nanoparticle tracking analysis of extracellular vesicles in the plasma of normal pregnant and pre-eclamptic women. Am. J. Obstet. Gynecol. 2014, 89, 151.

51. Rice, G.E.; Scholz-Romero, K.; Sweeney, E.; Peiris, H.; Kobayashi, M.; Duncombe, G.; Mitchell, M.D.; Salomon, C. The effect of glucose on the release and bioactivity of exosomes from first trimester trophoblast cells. J. Clin. Endocrinol. Metab. 2015, 100, E1280-E1288. [CrossRef]

52. Mitchell, M.D.; Peiris, H.N.; Kobayashi, M.; Koh, Y.Q.; Duncombe, G.; Illanes, S.E.; Rice, G.E.; Salomon, C. Placental exosomes in normal and complicated pregnancy. Am. J. Obstet. Gynecol. 2015, 213, S173-S181. [CrossRef]

53. Escudero, C.A.; Herlitz, K.; Troncoso, F.; Acurio, J.; Aguayo, C.; Roberts, J.M.; Truong, G.; Duncombe, G.; Rice, G.; Salomon, C. Role of extracellular vesicles and microRNAs on dysfunctional angiogenesis during preeclamptic pregnancies. Front. Physiol. 2016, 7, 98. [CrossRef] [PubMed]

54. Pillar, N.; Yoffe, L.; Hod, M.; Shomron, N. The possible involvement of microRNAs in preeclampsia and gestational diabetes mellitus. Best Pract. Res. Clin. Obstet. Gynaecol. 2015, 29, 176-182.

55. Mathivanan, S.; Ji, H.; Simpson, R.J. Exosomes: Extracellular organelles important in intercellular communication. J. Proteomics 2010, 73, 1907-1920. [CrossRef]

56. Gross, J.C.; Chaudhary, V.; Bartscherer, K.; Boutros, M. Active Wnt proteins are secreted on exosomes. Nat. Cell Biol. 2012, 14, 1036-1045. [CrossRef]

57. Matsumura, T.; Sugimachi, K.; Iinuma, H.; Takahashi, Y.; Kurashige, J.; Sawada, G.; Ueda, M.; Uchi, R.; Ueo, H.; Takano, Y.; et al. Exosomal microRNA in serum is a novel biomarker of recurrence in human colorectal cancer. Br. J. Cancer 2015, 113, 275-281. [CrossRef]

58. Colombo, M.; Raposo, G.; Théry, C. Biogenesis, Secretion and Intercellular Interactions of Exosomes and Other Extracellular Vesicles. Annu. Rev. Cell Dev. Biol. 2014, 30, 255-289. [CrossRef] [PubMed]

59. Schorey, J.S.; Bhatnagar, S. Exosome function: From tumor immunology to pathogen biology. Traffic 2008. [CrossRef] [PubMed]

60. Properzi, F.; Logozzi, M.; Fais, S. Exosomes: The future of biomarkers in medicine. Biomark. Med. 2013, 7, 769-778. [CrossRef] [PubMed]

61. Emanueli, C.; Shearn, A.I.U.; Laftah, A.; Fiorentino, F.; Reeves, B.C.; Beltrami, C.; Mumford, A.; Clayton, A.; Gurney, M.; Shantikumar, S.; et al. Coronary artery-bypass-graft surgery increases the plasma concentration of exosomes carrying a cargo of cardiac microRNAs: An example of exosome trafficking out of the human heart with potential for cardiac biomarker discovery. PLoS ONE 2016, 11, e0154274. [CrossRef]

62. Hill, A.F.; Pegtel, D.M.; Lambertz, U.; Leonardi, T.; O’Driscoll, L.; Pluchino, S.; Ter-Ovanesyan, D.; Nolte-'t Hoen, E.N.M. ISEV position paper: Extracellular vesicle RNA analysis and bioinformatics. J. Extracell. Vesicles 2013, 2. [CrossRef] [PubMed]

63. Théry, C.; Witwer, K.W.; Aikawa, E.; Alcaraz, M.J.; Anderson, J.D.; Andriantsitohaina, R.; Antoniou, A.; Arab, T.; Archer, F.; Atkin-Smith, G.K.; et al. Minimal information for studies of extracellular vesicles 2018 (MISEV2018): A position statement of the International Society for Extracellular Vesicles and update of the MISEV2014 guidelines. J. Extracell. Vesicles 2018, 7, 1535750. [CrossRef] [PubMed] 
64. Jay, S.M.; Vunjak-Novakovic, G. Extracellular Vesicles and Their Versatile Roles in Tissue Engineering. Tissue Eng. 2017, 23, 1210-1211. [CrossRef] [PubMed]

65. Lötvall, J.; Hill, A.F.; Hochberg, F.; Buzás, E.I.; Di Vizio, D.; Gardiner, C.; Gho, Y.S.; Kurochkin, I.V.; Mathivanan, S.; Quesenberry, P.; et al. Minimal experimental requirements for definition of extracellular vesicles and their functions: A position statement from the International Society for Extracellular Vesicles. J. Extracell. Vesicles 2014, 3. [CrossRef] [PubMed]

66. Mignot, G.; Roux, S.; Thery, C.; Ségura, E.; Zitvogel, L. Prospects for exosomes in immunotherapy of cancer. J. Cell. Mol. Med. 2006, 10, 376-388. [CrossRef] [PubMed]

67. Frydrychowicz, M.; Kolecka-Bednarczyk, A.; Madejczyk, M.; Yasar, S.; Dworacki, G. Exosomes-structure, biogenesis and biological role in non-small-cell lung cancer. Scand. J. Immunol. 2015, 81, 2-10.

68. Hannafon, B.N.; Ding, W.Q. Intercellular communication by exosome-derived microRNAs in cancer. Int. J. Mol. Sci. 2013, 14, 14240-14269. [CrossRef]

69. Mathivanan, S.; Fahner, C.J.; Reid, G.E.; Simpson, R.J. ExoCarta 2012: Database of exosomal proteins, RNA and lipids. Nucleic Acids Res. 2012, 66, 270-284. [CrossRef]

70. Treiber, T.; Treiber, N.; Plessmann, U.; Harlander, S.; Daiß, J.L.; Eichner, N.; Lehmann, G.; Schall, K.; Urlaub, H.; Meister, G. A Compendium of RNA-Binding Proteins that Regulate MicroRNA Biogenesis. Mol. Cell 2017. [CrossRef]

71. Zhang, J.; Li, S.; Li, L.; Li, M.; Guo, C.; Yao, J.; Mi, S. Exosome and exosomal microRNA: Trafficking, sorting and function. Genom. Proteom. Bioinf. 2015, 1, 17-24. [CrossRef] [PubMed]

72. Simpson, R.J.; Kalra, H.; Mathivanan, S. Exocarta as a resource for exosomal research. J. Extracell. Vesicles 2012, 1. [CrossRef]

73. Vishnubhatla, I.; Corteling, R.; Stevanato, L.; Hicks, C.; Sinden, J. The Development of Stem Cell-Derived Exosomes as a Cell-Free Regenerative Medicine. J. Circ. Biomarkers 2014, 166, 7309-7318. [CrossRef]

74. Théry, C.; Boussac, M.; Véron, P.; Ricciardi-Castagnoli, P.; Raposo, G.; Garin, J.; Amigorena, S. Proteomic Analysis of Dendritic Cell-Derived Exosomes: A Secreted Subcellular Compartment Distinct from Apoptotic Vesicles. J. Immunol. 2001. [CrossRef]

75. Gould, S.J.; Raposo, G. As we wait: Coping with an imperfect nomenclature for extracellular vesicles. J. Extracell. Vesicles 2013, 2. [CrossRef]

76. Elfeky, O.; Longo, S.; Lai, A.; Rice, G.E.; Salomon, C. Influence of maternal BMI on the exosomal profile during gestation and their role on maternal systemic inflammation. Placenta 2017, 50, 60-69. [CrossRef] [PubMed]

77. Salomon, C.; Kobayashi, M.; Ashman, K.; Sobrevia, L.; Mitchell, M.D.; Rice, G.E. Hypoxia-induced changes in the bioactivity of cytotrophoblast-derived exosomes. PLoS ONE 2013, 8, e79636. [CrossRef] [PubMed]

78. György, B.; Szabó, T.G.; Pásztói, M.; Pál, Z.; Misják, P.; Aradi, B.; László, V.; Pállinger, É.; Pap, E.; Kittel, Á.; et al. Membrane vesicles, current state-of-the-art: Emerging role of extracellular vesicles. Cell. Mol. Life Sci. 2011, 68, 2667-2688. [CrossRef] [PubMed]

79. Reiner, A.T.; Witwer, K.W.; Van Balkom, B.W.M.; De Beer, J.; Brodie, C.; Corteling, R.L.; Gabrielsson, S.; Gimona, M.; Ibrahim, A.G.; De Kleijn, D.; et al. Concise review: Developing best-practice models for the therapeutic use of extracellular vesicles. Stem Cells Transl. Med. 2017, 6, 1730-1739. [CrossRef] [PubMed]

80. Lener, T.; Gimona, M.; Aigner, L.; Börger, V.; Buzas, E.; Camussi, G.; Chaput, N.; Chatterjee, D.; Court, F.A.; del Portillo, H.A.; et al. Applying extracellular vesicles based therapeutics in clinical trials - An ISEV position paper. J. Extracell. Vesicles 2015, 4, 30087. [CrossRef] [PubMed]

81. Théry, C.; Amigorena, S.; Raposo, G.; Clayton, A. Isolation and Characterization of Exosomes from Cell Culture Supernatants and Biological Fluids. Curr. Protoc. Cell Biol. 2006, 30, 3-22. [CrossRef] [PubMed]

82. Momen-Heravi, F.; Balaj, L.; Alian, S.; Mantel, P.Y.; Halleck, A.E.; Trachtenberg, A.J.; Soria, C.E.; Oquin, S.; Bonebreak, C.M.; Saracoglu, E.; et al. Current methods for the isolation of extracellular vesicles. Biol. Chem. 2013, 394, 1253-1262. [CrossRef] [PubMed]

83. Witwer, K.W.; Buzás, E.I.; Bemis, L.T.; Bora, A.; Lässer, C.; Lötvall, J.; Nolte-'t Hoen, E.N.; Piper, M.G.; Sivaraman, S.; Skog, J.; et al. Standardization of sample collection, isolation and analysis methods in extracellular vesicle research. J. Extracell. Vesicles 2013, 2. [CrossRef] [PubMed]

84. Willis, G.R.; Kourembanas, S.; Mitsialis, S.A. Toward Exosome-Based Therapeutics: Isolation, Heterogeneity and Fit-for-Purpose Potency. Front. Cardiovasc. Med. 2017, 4, 63. [CrossRef] 
85. Li, P.; Kaslan, M.; Lee, S.H.; Yao, J.; Gao, Z. Progress in exosome isolation techniques. Theranostics 2017. [CrossRef]

86. Van der Pol, E.; Böing, A.N.; Gool, E.L.; Nieuwland, R. Recent developments in the nomenclature, presence, isolation, detection and clinical impact of extracellular vesicles. J. Thromb. Haemost. 2016, 14, 48-56. [CrossRef]

87. Nolte'T Hoen, E.N.M.; Buermans, H.P.J.; Waasdorp, M.; Stoorvogel, W.; Wauben, M.H.M.; 'T Hoen, P.A.C. Deep sequencing of RNA from immune cell-derived vesicles uncovers the selective incorporation of small non-coding RNA biotypes with potential regulatory functions. Nucleic Acids Res. 2012, 40, 9272-9285. [CrossRef]

88. Villarroya-Beltri, C.; Baixauli, F.; Gutiérrez-Vázquez, C.; Sánchez-Madrid, F.; Mittelbrunn, M. Sorting it out: Regulation of exosome loading. Semin. Cancer Biol. 2014, 28, 3-13. [CrossRef]

89. Bartel, D.P. MicroRNAs: Genomics, Biogenesis, Mechanism and Function. Cell 2004, 116, 281-297. [CrossRef]

90. Besnier, M.; Shantikumar, S.; Anwar, M.; Dixit, P.; Chamorro-Jorganes, A.; Sweaad, W.; Sala-Newby, G.; Madeddu, P.; Thomas, A.C.; Howard, L.; et al. miR-15a/-16 Inhibit Angiogenesis by Targeting the Tie2 Coding Sequence: Therapeutic Potential of a miR-15a/16 Decoy System in Limb Ischemia. Mol. Ther. Nucleic Acids 2019, 17, 49-62. [CrossRef]

91. Png, K.J.; Halberg, N.; Yoshida, M.; Tavazoie, S.F. A microRNA regulon that mediates endothelial recruitment and metastasis by cancer cells. Nature 2012, 481, 190-194. [CrossRef] [PubMed]

92. Gee, H.E.; Camps, C.; Buffa, F.M.; Colella, S.; Sheldon, H.; Gleadle, J.M.; Ragoussis, J.; Harris, A.L. MicroRNA-10b and breast cancer metastasis. Nature 2008, 455, E8-E9. [CrossRef] [PubMed]

93. Tay, Y.; Zhang, J.; Thomson, A.M.; Lim, B.; Rigoutsos, I. MicroRNAs to Nanog, Oct4 and Sox2 coding regions modulate embryonic stem cell differentiation. Nature 2008, 455, 1124-1128. [CrossRef] [PubMed]

94. Kota, J.; Chivukula, R.R.; O’Donnell, K.A.; Wentzel, E.A.; Montgomery, C.L.; Hwang, H.W.; Chang, T.C.; Vivekanandan, P.; Torbenson, M.; Clark, K.R.; et al. Therapeutic microRNA Delivery Suppresses Tumorigenesis in a Murine Liver Cancer Model. Cell 2009, 137, 1005-1017. [CrossRef]

95. Ma, L.; Teruya-Feldstein, J.; Weinberg, R.A. Tumour invasion and metastasis initiated by microRNA-10b in breast cancer. Nature 2007, 449, 682-688. [CrossRef]

96. Tabet, F.; Vickers, K.C.; Cuesta Torres, L.F.; Wiese, C.B.; Shoucri, B.M.; Lambert, G.; Catherinet, C.; Prado-Lourenco, L.; Levin, M.G.; Thacker, S.; et al. HDL-transferred microRNA-223 regulates ICAM-1 expression in endothelial cells. Nat. Commun. 2014, 5, 3292. [CrossRef]

97. Boon, R.A.; Vickers, K.C. Intercellular transport of MicroRNAs. Arterioscler. Thromb. Vasc. Biol. 2013, 33, 186-192. [CrossRef]

98. Arroyo, J.D.; Chevillet, J.R.; Kroh, E.M.; Ruf, I.K.; Pritchard, C.C.; Gibson, D.F.; Mitchell, P.S.; Bennett, C.F.; Pogosova-Agadjanyan, E.L.; Stirewalt, D.L.; et al. Argonaute2 complexes carry a population of circulating microRNAs independent of vesicles in human plasma. Proc. Natl. Acad. Sci. USA 2011, 108, 5003-5008. [CrossRef]

99. Gallo, A.; Tandon, M.; Alevizos, I.; Illei, G.G. The majority of microRNAs detectable in serum and saliva is concentrated in exosomes. PLoS ONE 2012, 7, e30679. [CrossRef]

100. Michael, A.; Bajracharya, S.D.; Yuen, P.S.T.; Zhou, H.; Star, R.A.; Illei, G.G.; Alevizos, I. Exosomes from human saliva as a source of microRNA biomarkers. Oral Dis. 2010, 16, 34-38. [CrossRef]

101. Lv, L.L.; Cao, Y.; Liu, D.; Xu, M.; Liu, H.; Tang, R.N.; Ma, K.L.; Liu, B.C. Isolation and quantification of MicroRNAs from urinary exosomes/microvesicles for biomarker discovery. Int. J. Biol. Sci. 2013, 9, 1021-1031. [CrossRef] [PubMed]

102. Zhou, Q.; Li, M.; Wang, X.; Li, Q.; Wang, T.; Zhu, Q.; Zhou, X.; Wang, X.; Gao, X.; Li, X. Immune-related microRNAs are abundant in breast milk exosomes. Int. J. Biol. Sci. 2011, 8, 118-123. [CrossRef] [PubMed]

103. Hu, Z.; Chen, X.; Zhao, Y.; Tian, T.; Jin, G.; Shu, Y.; Chen, Y.; Xu, L.; Zen, K.; Zhang, C.; et al. Serum microRNA signatures identified in a genome-wide serum microRNA expression profiling predict survival of non-small-cell lung cancer. J. Clin. Oncol. 2010, 28, 1721-1726. [CrossRef] [PubMed]

104. Kuroiwa, T.; Lee, E.G.; Danning, C.L.; Illei, G.G.; McInnes, I.B.; Boumpas, D.T. CD40 ligand-activated human monocytes amplify glomerular inflammatory responses through soluble and cell-to-cell contact-dependent mechanisms. J. Immunol. 1999, 163, 2168-2175.

105. Peng, B.; Chen, Y.; Leong, K.W. MicroRNA delivery for regenerative medicine. Adv. Drug Deliv. Rev. 2015, 88, 108-122. [CrossRef] 
106. Sen, C.K. MicroRNA in Regenerative Medicine; Elsevier: Amsterdam, The Netherlands, 2014; ISBN 9780124058583.

107. Pegtel, D.M.; Cosmopoulos, K.; Thorley-Lawson, D.A.; Van Eijndhoven, M.A.J.; Hopmans, E.S.; Lindenberg, J.L.; De Gruijl, T.D.; Würdinger, T.; Middeldorp, J.M. Functional delivery of viral miRNAs via exosomes. Proc. Natl. Acad. Sci. USA 2010, 107, 6328-6333. [CrossRef]

108. Meckes, D.G.; Shair, K.H.Y.; Marquitz, A.R.; Kung, C.P.; Edwards, R.H.; Raab-Traub, N. Human tumor virus utilizes exosomes for intercellular communication. Proc. Natl. Acad. Sci. USA 2010, 107, 20370-20375. [CrossRef]

109. Li, X.; Zhang, Z.; Beiter, T.; Schluesener, H.J. Nanovesicular vaccines: Exosomes. Arch. Immunol. Ther. Exp. 2005, 53, 329-335.

110. André, F.; Schartz, N.E.C.; Chaput, N.; Flament, C.; Raposo, G.; Amigorena, S.; Angevin, E.; Zitvogel, L. Tumor-derived exosomes: A new source of tumor rejection antigens. Vaccine 2002, 20, A28-A31. [CrossRef]

111. Chaput, N.; Andre, F.; Schartz, N.E.C.; Flament, C.; Angevin, E.; Zitvogel, L.; Escudier, B. Exosomes and anti-tumour immunotherapy. Bull. Cancer 2003, 8, 2165-2175.

112. Morse, M.A.; Garst, J.; Osada, T.; Khan, S.; Hobeika, A.; Clay, T.M.; Valente, N.; Shreeniwas, R.; Sutton, M.A.; Delcayre, A.; et al. A phase I study of dexosome immunotherapy in patients with advanced non-small cell lung cancer. J. Transl. Med. 2005, 3, 9. [CrossRef] [PubMed]

113. Dai, S.; Wei, D.; Wu, Z.; Zhou, X.; Wei, X.; Huang, H.; Li, G. Phase I clinical trial of autologous ascites-derived exosomes combined with GM-CSF for colorectal cancer. Mol. Ther. 2008, 16, 782-790. [CrossRef] [PubMed]

114. Viaud, S.; Ploix, S.; Lapierre, V.; Théry, C.; Commere, P.H.; Tramalloni, D.; Gorrichon, K.; Virault-Rocroy, P.; Tursz, T.; Lantz, O.; et al. Updated technology to produce highly immunogenic dendritic cell-derived exosomes of clinical grade: A critical role of interferon- $\gamma$. J. Immunother. 2011, 34, 65-75. [CrossRef] [PubMed]

115. Escudier, B.; Dorval, T.; Chaput, N.; André, F.; Caby, M.P.; Novault, S.; Flament, C.; Leboulaire, C.; Borg, C.; Amigorena, S.; et al. Vaccination of metastatic melanoma patients with autologous dendritic cell (DC) derived-exosomes: Results of the first phase 1 clinical trial. J. Transl. Med. 2005, 3, 10. [CrossRef] [PubMed]

116. Besse, B.; Charrier, M.; Lapierre, V.; Dansin, E.; Lantz, O.; Planchard, D.; Le Chevalier, T.; Livartoski, A.; Barlesi, F.; Laplanche, A.; et al. Dendritic cell-derived exosomes as maintenance immunotherapy after first line chemotherapy in NSCLC. Oncoimmunology 2016, 5, e1071008. [CrossRef]

117. Prajapati, K.; Perez, C.; Rojas, L.B.P.; Burke, B.; Guevara-Patino, J.A. Functions of NKG2D in CD8+ T cells: An opportunity for immunotherapy. Cell. Mol. Immunol. 2018, 15, 470-479. [CrossRef]

118. Viaud, S.; Terme, M.; Flament, C.; Taieb, J.; André, F.; Novault, S.; Escudier, B.; Robert, C.; Caillat-Zucman, S.; Tursz, T.; et al. Dendritic cell-derived exosomes promote natural killer cell activation and proliferation: A role for NKG2D ligands and IL-15R $\alpha$. PLOS ONE 2009, 4, e4942. [CrossRef]

119. Search of: MSC exosome - List Results - ClinicalTrials.gov. Available online: https://www.clinicaltrials. gov/ct2/results? cond=\&term $=$ MSC + exosome\&cntry=\&state $=\& c i t y=\&$ dist $=\& S e a r c h=$ Search $($ accessed on 29 December 2019).

120. Mendt, M.; Rezvani, K.; Shpall, E. Mesenchymal stem cell-derived exosomes for clinical use. Bone Marrow Transplant. 2019, 54, 789-792. [CrossRef]

121. A Study of CAP-1002 in Ambulatory and Non-Ambulatory Patients with Duchenne Muscular Dystrophy Full Text View - ClinicalTrials.gov. Available online: https://www.clinicaltrials.gov/ct2/show/NCT03406780? term=exosomes\&cond=treatment\&draw $=4 \&$ rank=29 (accessed on 2 January 2020).

122. Study Investigating the Ability of Plant Exosomes to Deliver Curcumin to Normal and Colon Cancer Tissue Full Text View - ClinicalTrials.gov. Available online: https://www.clinicaltrials.gov/ct2/show/NCT01294072? term=exosomes \%2CTherapy\%2C+Treatment\&draw=3\&rank=19 (accessed on 2 January 2020).

123. Plant Exosomes and Patients Diagnosed with Polycystic Ovary Syndrome (PCOS) 17 - Full Text View ClinicalTrials.gov. Available online: https://www.clinicaltrials.gov/ct2/show/NCT03493984?term=exosomes\% 2CTherapy\%2C+Treatment\&draw $=7 \&$ rank=54 (accessed on 2 January 2020).

124. Trial of a Vaccination With Tumor Antigen-loaded Dendritic Cell-derived Exosomes - Full Text View ClinicalTrials.gov. Available online: https://www.clinicaltrials.gov/ct2/show/NCT01159288?term=exosomes\% 2CTherapy\%2C+Treatment\&draw $=4 \&$ rank=29 (accessed on 2 January 2020).

125. iExosomes in Treating Participants With Metastatic Pancreas Cancer With KrasG12D Mutation - Full Text View - ClinicalTrials.gov. Available online: https:/clinicaltrials.gov/ct2/show/NCT03608631?term=exosomes\%2C+ MSC\%2C+Stromal\%2C+Therapy\%2C+Treatment\&draw=2\&rank=1 (accessed on 29 December 2019). 
126. MSC-Exos Promote Healing of MHs - Full Text View - ClinicalTrials.gov. Available online: https://linicaltrials.gov/ct2/show/NCT03437759?term=exosomes\%2CTherapy\%2C+Treatment\& cond $=$ macular\&draw $=2 \&$ rank $=1$ (accessed on 2 January 2020).

127. Effect of Microvesicles and Exosomes Therapy on $\beta$-cell Mass in Type I Diabetes Mellitus (T1DM) - Full Text View - ClinicalTrials.gov. Available online: https:/clinicaltrials.gov/ct2/show/NCT02138331?term= exosomes $\% 2$ CTherapy $\% 2 C+$ Treatment\&cond=Type+I+Diabetes\&draw=2\&rank=1 (accessed on 2 January 2020).

128. Effect of UMSCs Derived Exosomes on Dry Eye in Patients with cGVHD - Full Text View - ClinicalTrials.gov. Available online: https://www.clinicaltrials.gov/ct2/show/NCT04213248?term=exosomes\%2CTherapy\%2C+ Treatment\&draw=4\&rank=21 (accessed on 2 January 2020).

129. Focused Ultrasound and Exosomes to Treat Depression, Anxiety and Dementias - Full Text View ClinicalTrials.gov. Available online: https://www.clinicaltrials.gov/ct2/show/NCT04202770?term=exosomes\& cond $=$ treatment\&draw $=2 \&$ rank $=1$ (accessed on 2 January 2020).

130. The Use of Exosomes in Craniofacial Neuralgia - Full Text View - ClinicalTrials.gov. Available online: https://www.clinicaltrials.gov/ct2/show/NCT04202783?term=exosomes\%2CTherapy\% $2 \mathrm{C}+$ Treatment\&draw $=2 \&$ rank $=9$ (accessed on 2 January 2020).

131. Allogenic Mesenchymal Stem Cell Derived Exosome in Patients With Acute Ischemic Stroke - Full Text View - ClinicalTrials.gov. Available online: https:/clinicaltrials.gov/ct2/show/NCT03384433?term=exosomes\% 2CTherapy\%2C+Treatment\&cond=Stroke\&draw=2\&rank=1 (accessed on 2 January 2020).

132. Therapeutic Potential of Stem Cell Conditioned Medium on Chronic Ulcer Wounds - Full Text View ClinicalTrials.gov. Available online: https://www.clinicaltrials.gov/ct2/show/NCT04134676?term=exosomes\& cond=treatment\&draw=3\&rank=13 (accessed on 2 January 2020).

133. Ryther, R.C.C.; Flynt, A.S.; Phillips, J.A.; Patton, J.G. siRNA therapeutics: Big potential from small RNAs. Gene Ther. 2005, 12, 5-11. [CrossRef]

134. Koutsilieri, E.; Rethwilm, A.; Scheller, C. The therapeutic potential of siRNA in gene therapy of neurodegenerative disorders. J. Neural Transm. Suppl. 2007, 43-49.

135. Wahlgren, J.; Karlson, T.D.L.; Brisslert, M.; Vaziri Sani, F.; Telemo, E.; Sunnerhagen, P.; Valadi, H. Plasma exosomes can deliver exogenous short interfering RNA to monocytes and lymphocytes. Nucleic Acids Res. 2012, 40, e130. [CrossRef] [PubMed]

136. Alexander, M.; Hu, R.; Runtsch, M.C.; Kagele, D.A.; Mosbruger, T.L.; Tolmachova, T.; Seabra, M.C.; Round, J.L.; Ward, D.M.; O'Connell, R.M. Exosome-delivered microRNAs modulate the inflammatory response to endotoxin. Nat. Commun. 2015, 6, 7321. [CrossRef] [PubMed]

137. Voit, A.; Patel, V.; Pachon, R.; Shah, V.; Bakhutma, M.; Kohlbrenner, E.; McArdle, J.J.; Dell'Italia, L.J.; Mendell, J.R.; Xie, L.H.; et al. Reducing sarcolipin expression mitigates Duchenne muscular dystrophy and associated cardiomyopathy in mice. Nat. Commun. 2017, 8, 1068. [CrossRef] [PubMed]

138. Hulot, J.S.; Ishikawa, K.; Hajjar, R.J. Gene therapy for the treatment of heart failure: Promise postponed. Eur. Heart J. 2016, 37, 1651-1658. [CrossRef] [PubMed]

139. György, B.; Fitzpatrick, Z.; Crommentuijn, M.H.W.; Mu, D.; Maguire, C.A. Naturally enveloped AAV vectors for shielding neutralizing antibodies and robust gene delivery in vivo. Biomaterials 2014, 35, 7598-7609. [CrossRef] [PubMed]

140. Maguire, C.A.; Balaj, L.; Sivaraman, S.; Crommentuijn, M.H.W.; Ericsson, M.; Mincheva-Nilsson, L.; Baranov, V.; Gianni, D.; Tannous, B.A.; Sena-Esteves, M.; et al. Microvesicle-associated AAV vector as a novel gene delivery system. Mol. Ther. 2012, 20,960-971. [CrossRef] [PubMed]

141. Kooijmans, S.A.A.; Vader, P.; van Dommelen, S.M.; van Solinge, W.W.; Schiffelers, R.M. Exosome mimetics: A novel class of drug delivery systems. Int. J. Nanomed. 2012, 7, 1525-1541.

142. Lai, R.C.; Yeo, R.W.Y.; Tan, K.H.; Lim, S.K. Exosomes for drug delivery-A novel application for the mesenchymal stem cell. Biotechnol. Adv. 2013, 31, 543-551. [CrossRef]

143. Zhuang, X.; Xiang, X.; Grizzle, W.; Sun, D.; Zhang, S.; Axtell, R.C.; Ju, S.; Mu, J.; Zhang, L.; Steinman, L.; et al. Treatment of brain inflammatory diseases by delivering exosome encapsulated anti-inflammatory drugs from the nasal region to the brain. Mol. Ther. 2011, 19, 1769-1779. [CrossRef]

144. Batrakova, E.V.; Kim, M.S. Using exosomes, naturally-equipped nanocarriers, for drug delivery. J. Control. Release 2015, 219, 396-405. [CrossRef] 
145. Kalani, A.; Kamat, P.K.; Chaturvedi, P.; Tyagi, S.C.; Tyagi, N. Curcumin-primed exosomes mitigate endothelial cell dysfunction during hyperhomocysteinemia. Life Sci. 2014, 107, 1-7. [CrossRef] [PubMed]

146. Sun, D.; Zhuang, X.; Xiang, X.; Liu, Y.; Zhang, S.; Liu, C.; Barnes, S.; Grizzle, W.; Miller, D.; Zhang, H.G. A novel nanoparticle drug delivery system: The anti-inflammatory activity of curcumin is enhanced when encapsulated in exosomes. Mol. Ther. 2010, 18, 1606-1614. [CrossRef] [PubMed]

147. Kern, S.; Eichler, H.; Stoeve, J.; Klüter, H.; Bieback, K. Comparative Analysis of Mesenchymal Stem Cells from Bone Marrow, Umbilical Cord Blood or Adipose Tissue. Stem Cells 2006, 24, 1294-1301. [CrossRef]

148. Banas, A.; Teratani, T.; Yamamoto, Y.; Tokuhara, M.; Takeshita, F.; Quinn, G.; Okochi, H.; Ochiya, T. Adipose tissue-derived mesenchymal stem cells as a source of human hepatocytes. Hepatology 2007, 46, 219-228. [CrossRef] [PubMed]

149. Noort, W.A.; Scherjon, S.A.; Kleijburg-Van, D.K.C.; Kruisselbrink, A.B.; Van Bezooijen, R.L.; Beekhuizen, W.; Willemze, R.; Kanhai, H.H.H.; Fibbe, W.E. Mesenchymal stem cells in human second-trimester bone marrow, liver, lung and spleen exhibit a similar immunophenotype but a heterogeneous multilineage differentiation potential. Haematologica 2003, 88, 845-852.

150. Young, H.E.; Steele, T.A.; Bray, R.A.; Hudson, J.; Floyd, J.A.; Hawkins, K.; Thomas, K.; Austin, T.; Edwards, C.; Cuzzourt, J.; et al. Human reserve pluripotent mesenchymal stem cells are present in the connective tissues of skeletal muscle and dermis derived from fetal, adult and geriatric donors. Anat. Rec. 2001, 264, 51-62. [CrossRef]

151. Roubelakis, M.G.; Pappa, K.I.; Bitsika, V.; Zagoura, D.; Vlahou, A.; Papadaki, H.A.; Antsaklis, A.; Anagnou, N.P. Molecular and proteomic characterization of human mesenchymal stem cells derived from amniotic fluid: Comparison to bone marrow mesenchymal stem cells. Stem Cells Dev. 2007, 16, 931-952. [CrossRef]

152. Fukuchi, Y.; Nakajima, H.; Sugiyama, D.; Hirose, I.; Kitamura, T.; Tsuji, K. Human Placenta-Derived Cells Have Mesenchymal Stem/Progenitor Cell Potential. Stem Cells 2004, 22, 649-658. [CrossRef]

153. Miao, Z.; Jin, J.; Chen, L.; Zhu, J.; Huang, W.; Zhao, J.; Qian, H.; Zhang, X. Isolation of mesenchymal stem cells from human placenta: Comparison with human bone marrow mesenchymal stem cells. Cell Biol. Int. 2006, 30, 681-687. [CrossRef]

154. Brooke, G.; Cook, M.; Blair, C.; Han, R.; Heazlewood, C.; Jones, B.; Kambouris, M.; Kollar, K.; McTaggart, S.; Pelekanos, R.; et al. Therapeutic applications of mesenchymal stromal cells. Semin. Cell Dev. Biol. 2007, 18, 846-858. [CrossRef]

155. Mesenchymal stem cells derived from dental tissues vs. those from other sources: Their biology and role in regenerative medicine. - PubMed - NCBI. Available online: https://www.ncbi.nlm.nih.gov/pubmed/19767575 (accessed on 28 December 2019).

156. Lian, Q.; Lye, E.; Suan Yeo, K.; Khia Way Tan, E.; Salto-Tellez, M.; Liu, T.M.; Palanisamy, N.; El Oakley, R.M.; Lee, E.H.; Lim, B.; et al. Derivation of Clinically Compliant MSCs from CD105+, CD24- Differentiated Human ESCs. Stem Cells 2007, 25, 425-436. [CrossRef]

157. Yeo, R.W.Y.; Lai, R.C.; Zhang, B.; Tan, S.S.; Yin, Y.; Teh, B.J.; Lim, S.K. Mesenchymal stem cell: An efficient mass producer of exosomes for drug delivery. Adv. Drug Deliv. Rev. 2013, 65, 336-341. [CrossRef] [PubMed]

158. Munagala, R.; Aqil, F.; Jeyabalan, J.; Gupta, R.C. Bovine milk-derived exosomes for drug delivery. Cancer Lett. 2016, 371, 48-61. [CrossRef]

159. Sarker, S.; Scholz-Romero, K.; Perez, A.; Illanes, S.E.; Mitchell, M.D.; Rice, G.E.; Salomon, C. Placenta-derived exosomes continuously increase in maternal circulation over the first trimester of pregnancy. J. Transl. Med. 2014, 12, 204. [CrossRef] [PubMed]

160. Salomon, C.; Torres, M.J.; Kobayashi, M.; Scholz-Romero, K.; Sobrevia, L.; Dobierzewska, A.; Illanes, S.E.; Mitchell, M.D.; Rice, G.E. A gestational profile of placental exosomes in maternal plasma and their effects on endothelial cell migration. PLoS ONE 2014, 9, e98667. [CrossRef] [PubMed]

161. Salomon, C.; Scholz-Romero, K.; Sarker, S.; Sweeney, E.; Kobayashi, M.; Correa, P.; Longo, S.; Duncombe, G.; Mitchell, M.D.; Rice, G.E.; et al. Gestational diabetes mellitus is associated with changes in the concentration and bioactivity of placenta-derived exosomes in maternal circulation across gestation. Diabetes 2016, 65, 598-609. [CrossRef]

162. Nakahara, A.; Elfeky, O.; Garvey, C.; Guanzon, D.; Longo, S.A.; Salmon, C. Exosome Profiles for Normal and Complicated Pregnancies-A Longitudinal Study [3O]. Obstet. Gynecol. 2019, 133, 162. [CrossRef] 
163. Salomon, C.; Sobrevia, L.; Ashman, K.; Illanes, S.; Mitchell, M.D.; Rice, G.E. The Role of Placental Exosomes in Gestational Diabetes Mellitus. In Gestational Diabetes-Causes, Diagnosis and Treatment; Sobrevia, L., Ed.; InTech: Rijeka, Croatia, 2013; pp. 29-47.

164. Jayabalan, N.; Lai, A.; Nair, S.; Guanzon, D.; Scholz-Romero, K.; Palma, C.; McIntyre, H.D.; Lappas, M.; Salomon, C. Quantitative Proteomics by SWATH-MS Suggest an Association Between Circulating Exosomes and Maternal Metabolic Changes in Gestational Diabetes Mellitus. Proteomics 2019, 19, e1800164. [CrossRef]

165. Jayabalan, N.; Ormazabal, V.; Lai, A.; Lappas, M.; Salomon, C. Proteomic Profile of Adipose Tissue-Derived Exosomes and Their Potential Role on Placental Glucose Metabolism in Gestational Diabetes Mellitus. Diabetes 2018. [CrossRef]

166. Jayabalan, N.; Nair, S.; Nuzhat, Z.; Rice, G.E.; Zuñiga, F.A.; Sobrevia, L.; Leiva, A.; Sanhueza, C.; Gutiérrez, J.A.; Lappas, M.; et al. Cross talk between adipose tissue and placenta in obese and gestational diabetes mellitus pregnancies via exosomes. Front. Endocrinol. 2017, 8, 239. [CrossRef]

167. Sáez, T.; de Vos, P.; Sobrevia, L.; Faas, M.M. Is there a role for exosomes in foetoplacental endothelial dysfunction in gestational diabetes mellitus? Placenta 2018, 61, 48-54. [CrossRef]

168. Arrial, R.T.; Togawa, R.C.; Marcelo, M.M. Screening non-coding RNAs in transcriptomes from neglected species using PORTRAIT: Case study of the pathogenic fungus Paracoccidioides brasiliensis. BMC Bioinform. 2009, 10, 239. [CrossRef]

169. Ausubel, F.M.; Brent, R.; Kingston, R.E.; Moore, D.D.; Seidman, J.G.; Smith, J.A.; Struhl, K. Current Protocols in Molecular Biology: Preface. Curr. Protoc. Mol. Biol. 2010. [CrossRef]

170. Boutet, S.C.; Cheung, T.H.; Quach, N.L.; Liu, L.; Prescott, S.L.; Edalati, A.; Iori, K.; Rando, T.A. Alternative polyadenylation mediates microRNA regulation of muscle stem cell function. Cell Stem Cell 2012, 10, 327-336. [CrossRef] [PubMed]

171. Ballarino, M.; Cazzella, V.; D’Andrea, D.; Grassi, L.; Bisceglie, L.; Cipriano, A.; Santini, T.; Pinnarò, C.; Morlando, M.; Tramontano, A.; et al. Novel Long Noncoding RNAs (lncRNAs) in Myogenesis: A miR-31 Overlapping lncRNA Transcript Controls Myoblast Differentiation. Mol. Cell. Biol. 2015, 35, 728-736. [CrossRef] [PubMed]

172. Bergmann, J.H.; Spector, D.L. Long non-coding RNAs: Modulators of nuclear structure and function. Curr. Opin. Cell Biol. 2014, 26, 10-18. [CrossRef] [PubMed]

173. Buckingham, M.; Relaix, F. The Role of Pax Genes in the Development of Tissues and Organs: Pax3 and Pax7 Regulate Muscle Progenitor Cell Functions. Annu. Rev. Cell Dev. Biol. 2007, 23, 645-673. [CrossRef]

174. Buckingham, M.; Rigby, P.W.J. Gene Regulatory Networks and Transcriptional Mechanisms that Control Myogenesis. Dev. Cell 2014, 28, 225-238. [CrossRef]

175. Cabili, M.; Trapnell, C.; Goff, L.; Koziol, M.; Tazon-Vega, B.; Regev, A.; Rinn, J.L. Integrative annotation of human large intergenic noncoding RNAs reveals global properties and specific subclasses. Genes Dev. 2011, 25, 1915-1927. [CrossRef]

176. Güller, I.; Russell, A.P. MicroRNAs in skeletal muscle: Their role and regulation in development, disease and function. J. Physiol. 2010, 588, 4075-4087. [CrossRef]

177. Catapano, F.; Domingos, J.; Perry, M.; Ricotti, V.; Phillips, L.; Servais, L.; Seferian, A.; de Groot, I.; Krom, Y.D.; Niks, E.H.; et al. Downregulation of miRNA-29, -23 and -21 in urine of Duchenne muscular dystrophy patients. Epigenomics 2018, 10, 875-889. [CrossRef] [PubMed]

178. Cacchiarelli, D.; Incitti, T.; Martone, J.; Cesana, M.; Cazzella, V.; Santini, T.; Sthandier, O.; Bozzoni, I. MiR-31 modulates dystrophin expression: New implications for Duchenne muscular dystrophy therapy. EMBO Rep. 2011, 12, 136-141. [CrossRef] [PubMed]

179. Rahimi, G.; Jafari, N.; Khodabakhsh, M.; Shirzad, Z.; Dogaheh, H.P. Upregulation of microRNA processing enzymes drosha and dicer in gestational diabetes mellitus. Gynecol. Endocrinol. 2015, 31, 156-159. [CrossRef]

180. Wander, P.L.; Boyko, E.J.; Hevner, K.; Parikh, V.J.; Tadesse, M.G.; Sorensen, T.K.; Williams, M.A.; Enquobahrie, D.A. Circulating early- and mid-pregnancy microRNAs and risk of gestational diabetes. Diabetes Res. Clin. Pract. 2017, 132, 1-9. [CrossRef] [PubMed]

181. Cao, Y.L.; Jia, Y.J.; Xing, B.H.; Shi, D.D.; Dong, X.J. Plasma microRNA-16-5p, -17-5p and -20a-5p: Novel diagnostic biomarkers for gestational diabetes mellitus. J. Obstet. Gynaecol. Res. 2017, 43, 974-981. [CrossRef] [PubMed] 
182. Li, J.; Song, L.; Zhou, L.; Wu, J.; Sheng, C.; Chen, H.; Liu, Y.; Gao, S.; Huang, W. A MicroRNA signature in gestational diabetes mellitus associated with risk of macrosomia. Cell. Physiol. Biochem. 2015, 37, $243-252$. [CrossRef] [PubMed]

183. Zhao, C.; Zhang, T.; Shi, Z.; Ding, H.; Ling, X. MicroRNA-518d regulates PPAR $\alpha$ protein expression in the placentas of females with gestational diabetes mellitus. Mol. Med. Rep. 2014, 9, 2085-2090. [CrossRef] [PubMed]

184. Shi, Z.; Zhao, C.; Guo, X.; Ding, H.; Cui, Y.; Shen, R.; Liu, J. Differential expression of micrornas in omental adipose tissue from gestational diabetes mellitus subjects reveals mir-222 as a regulator of er $\alpha$ expression in estrogen-induced insulin resistance. Endocrinology 2014, 155, 1982-1990. [CrossRef]

185. Hunter, M.P.; Ismail, N.; Zhang, X.; Aguda, B.D.; Lee, E.J.; Yu, L.; Xiao, T.; Schafer, J.; Lee, M.L.T.; Schmittgen, T.D.; et al. Detection of microRNA expression in human peripheral blood microvesicles. PLoS ONE 2008, 3, e3694. [CrossRef]

186. Donker, R.B.; Mouillet, J.F.; Chu, T.; Hubel, C.A.; Stolz, D.B.; Morelli, A.E.; Sadovsky, Y. The expression profile of C19MC microRNAs in primary human trophoblast cells and exosomes. Mol. Hum. Reprod. 2012, 18, 417-424. [CrossRef]

187. Ferrari, G.; Cusella-De Angelis, G.; Coletta, M.; Paolucci, E.; Stornaiuolo, A.; Cossu, G.; Mavilio, F. Muscle regeneration by bone marrow-derived myogenic progenitors. Science 1998, 5356, 1528-1530. [CrossRef] [PubMed]

188. Barry, F.P.; Murphy, J.M. Mesenchymal stem cells: Clinical applications and biological characterization. Int. J. Biochem. Cell Biol. 2004, 4, 568-584. [CrossRef] [PubMed]

189. Gang, E.J. Skeletal Myogenic Differentiation of Mesenchymal Stem Cells Isolated from Human Umbilical. Cord Blood Stem Cells 2004, 22, 617-624. [CrossRef] [PubMed]

190. Ullah, I.; Baregundi Subbarao, R.; Rho, G.-J. Human Mesenchymal Stem Cells-Current trends and future prospective. Biosci. Rep. 2015, 35, e00191. [CrossRef]

191. Xin, H.; Li, Y.; Chopp, M. Exosomes/miRNAs as mediating cell-based therapy of stroke. Front. Cell. Neurosci. 2014, 8. [CrossRef]

192. Vagnozzi, R.J.; Maillet, M.; Sargent, M.A.; Khalil, H.; Johansen, A.K.; Schwanekamp, J.A.; York, A.J.; Huang, V.; Nahrendorf, M.; Sadayappan, S.; et al. An acute immune response underlies the benefit of cardiac stem-cell therapy. Nature 2019, 577, 405-409. [CrossRef]

193. Pelekanos, R.A.; Sardesai, V.S.; Futrega, K.; Lott, W.B.; Kuhn, M.; Doran, M.R. Isolation and expansion of mesenchymal stem/stromal cells derived from human placenta tissue. J. Vis. Exp. 2016, 2016, 12. [CrossRef]

194. Mathiyalagan, P.; Liang, Y.; Kim, D.; Misener, S.; Thorne, T.; Kamide, C.E.; Klyachko, E.; Losordo, D.W.; Hajjar, R.J.; Sahoo, S. Angiogenic Mechanisms of Human CD34 + Stem Cell Exosomes in the Repair of Ischemic Hindlimb. Circ. Res. 2017, 120, 1466-1476. [CrossRef]

195. Khare, D.; Or, R.; Resnick, I.; Barkatz, C.; Almogi-Hazan, O.; Avni, B. Mesenchymal Stromal Cell-Derived Exosomes Affect mRNA Expression and Function of B-Lymphocytes. Front. Immunol. 2018, 9, 3053. [CrossRef]

196. Burrello, J.; Monticone, S.; Gai, C.; Gomez, Y.; Kholia, S.; Camussi, G. Stem Cell-Derived Extracellular Vesicles and Immune-Modulation. Front. cell Dev. Biol. 2016, 4, 83. [CrossRef]

197. Willis, G.R.; Fernandez-Gonzalez, A.; Reis, M.; Mitsialis, S.A.; Kourembanas, S. Macrophage Immunomodulation: The Gatekeeper for Mesenchymal Stem Cell Derived-Exosomes in Pulmonary Arterial Hypertension? Int. J. Mol. Sci. 2018, 19, 2534. [CrossRef] [PubMed]

198. Willis, G.R.; Fernandez-Gonzalez, A.; Anastas, J.; Vitali, S.H.; Liu, X.; Ericsson, M.; Kwong, A.; Mitsialis, S.A.; Kourembanas, S. Mesenchymal Stromal Cell Exosomes Ameliorate Experimental Bronchopulmonary Dysplasia and Restore Lung Function through Macrophage Immunomodulation. Am. J. Respir. Crit. Care Med. 2018, 197, 104-116. [CrossRef] [PubMed]

199. Beltrami, C.; Besnier, M.; Shantikumar, S.; Shearn, A.I.U.; Rajakaruna, C.; Laftah, A.; Sessa, F.; Spinetti, G.; Petretto, E.; Angelini, G.D.; et al. Human Pericardial Fluid Contains Exosomes Enriched with Cardiovascular-Expressed MicroRNAs and Promotes Therapeutic Angiogenesis. Mol. Ther. 2017, 3, 679-693. [CrossRef]

200. Vicencio, J.M.; Yellon, D.M.; Sivaraman, V.; Das, D.; Boi-Doku, C.; Arjun, S.; Zheng, Y.; Riquelme, J.A.; Kearney, J.; Sharma, V.; et al. Plasma exosomes protect the myocardium from ischemia-reperfusion injury. J. Am. Coll. Cardiol. 2015, 65, 1525-1536. [CrossRef] 
201. Davidson, S.M.; Riquelme, J.A.; Takov, K.; Vicencio, J.M.; Boi-Doku, C.; Khoo, V.; Doreth, C.; Radenkovic, D.; Lavandero, S.; Yellon, D.M. Cardioprotection mediated by exosomes is impaired in the setting of type II diabetes but can be rescued by the use of non-diabetic exosomes in vitro. J. Cell. Mol. Med. 2018, 22, 141-151. [CrossRef] [PubMed]

202. Sahoo, S.; Emanueli, C. Exosomes in diabetic cardiomyopathy: The next-generation therapeutic targets? Diabetes 2016, 65, 2829-2831. [CrossRef] [PubMed]

203. Zhao, T.; Sun, F.; Liu, J.; Ding, T.; She, J.; Mao, F.; Xu, W.; Qian, H.; Yan, Y. Emerging Role of Mesenchymal Stem Cell-derived Exosomes in Regenerative Medicine. Curr. Stem Cell Res. Ther. 2019, 14, 482-494. [CrossRef] [PubMed]

204. Arslan, F.; Lai, R.C.; Smeets, M.B.; Akeroyd, L.; Choo, A.; Aguor, E.N.E.; Timmers, L.; van Rijen, H.V.; Doevendans, P.A.; Pasterkamp, G.; et al. Mesenchymal stem cell-derived exosomes increase ATP levels, decrease oxidative stress and activate PI3K/Akt pathway to enhance myocardial viability and prevent adverse remodeling after myocardial ischemia/reperfusion injury. Stem Cell Res. 2013, 10, 301-312. [CrossRef]

205. Takeda, K.; Webb, T.L.; Ning, F.; Shiraishi, Y.; Regan, D.P.; Chow, L.; Smith, M.J.; Ashino, S.; Guth, A.M.; Hopkins, S.; et al. Mesenchymal Stem Cells Recruit CCR2+ Monocytes to Suppress Allergic Airway Inflammation. J. Immunol. 2018, 200, 1261-1269. [CrossRef]

206. Qin, Z.H.; Xu, J.F.; Qu, J.M.; Zhang, J.; Sai, Y.; Chen, C.M.; Wu, L.; Yu, L. Intrapleural delivery of MSCs attenuates acute lung injury by paracrine/endocrine mechanism. J. Cell. Mol. Med. 2012, 16, 2745-2753. [CrossRef]

207. Fuster-Matanzo, A.; Gessler, F.; Leonardi, T.; Iraci, N.; Pluchino, S. Acellular approaches for regenerative medicine: On the verge of clinical trials with extracellular membrane vesicles? Extracellular vesicles and regenerative medicine. Stem Cell Res. Ther. 2015, 6, 227. [CrossRef]

208. Lin, C.-S.; Lue, T.F. Stem Cell Therapy for Stress Urinary Incontinence: A Critical Review. Stem Cells Dev. 2012, 21, 834-843. [CrossRef]

209. Ho, C.P.; Bhatia, N.N. Development of stem cell therapy for stress urinary incontinence. Curr. Opin. Obstet. Gynecol. 2012, 24, 311-317. [CrossRef]

210. Marquez-Curtis, L.A.; Janowska-Wieczorek, A. Enhancing the migration ability of mesenchymal stromal cells by targeting the SDF-1/CXCR4 axis. Biomed Res. Int. 2013, 561098. [CrossRef]

211. Rani, S.; Ryan, A.E.; Griffin, M.D.; Ritter, T. Mesenchymal Stem Cell-derived Extracellular Vesicles: Toward Cell-free Therapeutic Applications. Mol. Ther. 2015, 23, 812-823. [CrossRef]

212. de Jong, O.G.; van Balkom, B.W.M.; Schiffelers, R.M.; Bouten, C.V.C.; Verhaar, M.C. Extracellular vesicles: Potential roles in regenerative medicine. Front. Immunol. 2014, 5, 608. [CrossRef] [PubMed]

213. Ni, J.; Li, H.; Zhou, Y.; Gu, B.; Xu, Y.; Fu, Q.; Peng, X.; Cao, N.; Fu, Q.; Jin, M.; et al. Cellular Physiology and Biochemistry Cellular Physiology and Biochemistry Original Paper Therapeutic Potential of Human Adipose-Derived Stem Cell Exosomes in Stress Urinary Incontinence-An in Vitro and in Vivo Study Cellular Physiology and Biochemistry Cellular Physiology and Biochemistry. Cell Physiol. Biochem. 2018, 48, 1710-1722.

214. Liu, X.; Wang, S.; Wu, S.; Hao, Q.; Li, Y.; Guo, Z.; Wang, W. Exosomes secreted by adipose-derived mesenchymal stem cells regulate type i collagen metabolism in fibroblasts from women with stress urinary incontinence. Stem Cell Res. Ther. 2018, 9, 159. [CrossRef]

215. Liu, X.; Wu, S.; Wang, W.; Hao, Q.; Guo, Z.; Wang, W. Regulatory effect of exosomes secreted by vaginal wall fibroblasts on angiogenesis in patients with stress urinary incontinence. Natl. Med. J. China 2019, 99, 510-514.

216. Wu, R.; Huang, C.; Wu, Q.; Jia, X.; Liu, M.; Xue, Z.; Qiu, Y.; Niu, X.; Wang, Y. Exosomes secreted by urine-derived stem cells improve stress urinary incontinence by promoting repair of pubococcygeus muscle injury in rats. Stem Cell Res. Ther. 2019, 10, 80. [CrossRef]

217. Thiruvikrama Prakash, G.; Das, A.K.; Habeebullah, S.; Bhat, V.; Shamanna, S.B. Maternal and neonatal outcome in mothers with gestational diabetes mellitus. Indian J. Endocrinol. Metab. 2017, 21, 854-858. [PubMed]

218. Zetterström, K.; Lindeberg, S.N.; Haglund, B.; Hanson, U. Maternal complications in women with chronic hypertension: A population-based cohort study. Acta Obstet. Gynecol. Scand. 2005, 84, 419-424. [CrossRef]

219. Leon, M.G.; Moussa, H.N.; Longo, M.; Pedroza, C.; Haidar, Z.A.; Mendez-Figueroa, H.; Blackwell, S.C.; Sibai, B.M. Rate of Gestational Diabetes Mellitus and Pregnancy Outcomes in Patients with Chronic Hypertension. Am. J. Perinat. 2016, 33, 745-750. 
220. Lamichhane, T.N.; Sokic, S.; Schardt, J.S.; Raiker, R.S.; Lin, J.W.; Jay, S.M. Emerging Roles for Extracellular Vesicles in Tissue Engineering and Regenerative Medicine. Tissue Eng. Part B Rev. 2014, 21, 45-54. [CrossRef]

221. Zhang, B.; Wu, X.; Zhang, X.; Sun, Y.; Yan, Y.; Shi, H.; Zhu, Y.; Wu, L.; Pan, Z.; Zhu, W.; et al. Human Umbilical Cord Mesenchymal Stem Cell Exosomes Enhance Angiogenesis Through the Wnt4/ß-Catenin Pathway. Stem Cells Transl. Med. 2015, 4, 513-522. [CrossRef]

222. Umezu, T.; Tadokoro, H.; Azuma, K.; Yoshizawa, S.; Ohyashiki, K.; Ohyashiki, J.H. Exosomal miR-135b shed from hypoxic multiple myeloma cells enhances angiogenesis by targeting factor-inhibiting HIF-1. Blood 2014, 124, 3748-3757. [CrossRef]

223. Shabbir, A.; Cox, A.; Rodriguez-Menocal, L.; Salgado, M.; Van Badiavas, E. Mesenchymal Stem Cell Exosomes Induce Proliferation and Migration of Normal and Chronic Wound Fibroblasts and Enhance Angiogenesis in Vitro. Stem Cells Dev. 2015, 24, 1635-1647. [CrossRef]

224. Sahoo, S.; Klychko, E.; Thorne, T.; Misener, S.; Schultz, K.M.; Millay, M.; Ito, A.; Liu, T.; Kamide, C.; Agrawal, H.; et al. Exosomes from human CD34+ stem cells mediate their proangiogenic paracrine activity. Circ. Res. 2011, 109, 724-728. [CrossRef]

225. Liang, X.; Zhang, L.; Wang, S.; Han, Q.; Zhao, R.C. Exosomes secreted by mesenchymal stem cells promote endothelial cell angiogenesis by transferring miR-125a. J. Cell Sci. 2016, 129, 2182-2189. [CrossRef]

226. Blazquez, R.; Sanchez-Margallo, F.M.; de la Rosa, O.; Dalemans, W.; Álvarez, V.; Tarazona, R.; Casado, J.G. Immunomodulatory potential of human adipose mesenchymal stem cells derived exosomes on in vitro stimulated T cells. Front. Immunol. 2014, 5, 556. [CrossRef]

227. Kshirsagar, S.K.; Alam, S.M.; Jasti, S.; Hodes, H.; Nauser, T.; Gilliam, M.; Billstrand, C.; Hunt, J.S.; Petroff, M.G. Immunomodulatory molecules are released from the first trimester and term placenta via exosomes. Placenta 2012, 33, 982-990. [CrossRef]

228. Chen, W.; Huang, Y.; Han, J.; Yu, L.; Li, Y.; Lu, Z.; Li, H.; Liu, Z.; Shi, C.; Duan, F.; et al. Immunomodulatory effects of mesenchymal stromal cells-derived exosome. Immunol. Res. 2016, 64, 831-840. [CrossRef]

229. Altevogt, P.; Bretz, N.P.; Ridinger, J.; Utikal, J.; Umansky, V. Novel insights into exosome-induced, tumor-associated inflammation and immunomodulation. Semin. Cancer Biol. 2014, 28, 51-57. [CrossRef]

230. Zhang, B.; Yin, Y.; Lai, R.C.; Tan, S.S.; Choo, A.B.H.; Lim, S.K. Mesenchymal stem cells secrete immunologically active exosomes. Stem Cells Dev. 2014, 23, 1233-1244. [CrossRef]

231. Borges, F.T.; Melo, S.A.; Özdemir, B.C.; Kato, N.; Revuelta, I.; Miller, C.A.; Gattone, V.H.; LeBleu, V.S.; Kalluri, R. TGF- $\beta 1$-Containing exosomes from injured epithelial cells activate fibroblasts to initiate tissue regenerative responses and fibrosis. J. Am. Soc. Nephrol. 2013, 24, 385-392. [CrossRef] [PubMed]

232. Zhang, S.; Chu, W.C.; Lai, R.C.; Lim, S.K.; Hui, J.H.P.; Toh, W.S. Exosomes derived from human embryonic mesenchymal stem cells promote osteochondral regeneration. Osteoarthr. Cartil. 2016, 24, 2135-2140. [CrossRef] [PubMed]

233. Nakamura, Y.; Miyaki, S.; Ishitobi, H.; Matsuyama, S.; Nakasa, T.; Kamei, N.; Akimoto, T.; Higashi, Y.; Ochi, M. Mesenchymal-stem-cell-derived exosomes accelerate skeletal muscle regeneration. FEBS Lett. 2015, 589, 1257-1265. [CrossRef] [PubMed]

234. Tao, S.C.; Yuan, T.; Zhang, Y.L.; Yin, W.J.; Guo, S.C.; Zhang, C.Q. Exosomes derived from miR-140-5p-overexpressing human synovial mesenchymal stem cells enhance cartilage tissue regeneration and prevent osteoarthritis of the knee in a rat model. Theranostics 2017, 7, 180-195. [CrossRef] [PubMed]

235. Huang, C.C.; Narayanan, R.; Alapati, S.; Ravindran, S. Exosomes as biomimetic tools for stem cell differentiation: Applications in dental pulp tissue regeneration. Biomaterials 2016, 111, 103-115. [CrossRef] [PubMed]

(C) 2020 by the authors. Licensee MDPI, Basel, Switzerland. This article is an open access article distributed under the terms and conditions of the Creative Commons Attribution (CC BY) license (http://creativecommons.org/licenses/by/4.0/). 